\title{
THE IMPACT OF THE COMPETITION POLICY ON ECONOMIC DEVELOPMENT IN THE CASE OF DEVELOPING COUNTRIES
}

\author{
Sinisa Milosevic ${ }^{1}$, Dejan Trifunovic ${ }^{2 *}$ and Jelena Popovic Markopoulos ${ }^{1}$ \\ ${ }^{1}$ Commission for Protection of Competition, The Republic of Serbia \\ ${ }^{2}$ Faculty of Economics, University of Belgrade, Belgrade, The Republic of Serbia
}

In this paper, we will analyse the impact of the effective application of the competition policy to the economic development of developing countries. Many empirical papers suggest that the existence of the competition policy does not significantly affect the level of the GDP per capita, and that only its effective application is important. We will take the same approach and use the World Economic Forum index as a proxy for the effective application of the competition policy. We will demonstrate that a part of the variations in the GDP per capita between developing countries could be explained by an effective application of the competition policy.

Ključne reči: competition policy, intensity of competition, economic development, developing countries

\section{JEL Classification: L51, 012}

\section{INTRODUCTION}

The objective of this research is to examine the impact the competition policy has on the economic development of developing countries. Although this policy has been in existence in the world for more than a century, in some countries it does not have a long history of application. Its main function is to contribute to an increase in welfare and to increase the efficiency and productivity of the entire economy. Most countries intend to formulate a sustainable growth strategy that will provide a better standard

* Correspondence to: D. Trifunovic, Faculty of Economics, University of Belgrade, Kamenicka 6, 11000 Belgrade, The Republic of Serbia; e-mail: dejan@ekof.bg.ac.rs of living. Such circumstances have led to a change in the paradigm of economic development, so that developing countries are increasingly shifting to solving internal problems, as their impact at the global level is limited.

One of the basic internal problems of developing countries is certainly solving the issue of the competition protection policy. The adoption of a regulatory framework and the establishment of a regulatory agency in this area are also conditions for admission to the full membership in the European Union. There is extensive literature on the competition policy, and within it, there are the theoretically founded claims that the implementation of such a 
policy contributes to the economic progress and wellbeing of the entire society. The question imposing itself is whether this is achieved in practice, and above all whether this applies to developing countries.

The objective of this paper is directed towards testing the following hypothesis:

$\mathrm{H}$ : The effective enforcement of the competition policy has a positive impact on the economic development of developing countries.

To test this hypothesis, the indicators of the effective application of the competition and economic development policy will be formulated.

This research study is aimed at demonstrating the fact that there is a positive impact of an effectively guided competition policy on the economic development of developing countries. In addition, its objective is also to contribute to understanding the importance that the competition policy has within the regulatory framework of a country's economy. If the accuracy of the hypothesis is confirmed, developing countries should pay greater attention to the development and implementation of the competition policy due to the processes and changes occurring in their markets. The competition policy directly influences the decisions made by individual economic entities. In this way, it also has an indirect impact on consumers, on the one hand, and the whole economy, on the other.

The rest of the paper is organized as follows; in the second part, a brief overview of the literature that examines the impact of the competition policy on economic development is presented. In the third part, the methodology for selecting a sample of countries for the purpose of conducting our empirical analysis is explained. In the fourth part, an explanation for the selection of the independent variables is given, and their behavior in developing countries is analyzed. In the main part of the paper, the hypothesis that there is a positive impact of the effective application of the competition policy on the economic development of developing countries is tested. The last part of the paper is reserved for the conclusion.

\section{LITERATURE REVIEW}

According to the convergence hypothesis, developing countries should have a higher rate of economic growth than developed countries. However, the continuation of sustainable economic development and the convergence of developing countries were undermined during the global economic crisis. In such an environment of slow economic progress at a global level, developing countries should pay more attention to the internal issues that could contribute to their economic growth.

Competition encourages market participants to be more efficient and to offer a greater choice of products and services at lower prices. At the same time, competition increases economic efficiency, through a reduction in production costs, technological progress and innovation. Even though the protection of competition may increase welfare due to the previously mentioned reasons, the competition policy might often be in conflict with other policy objectives.

In the past, most jurisdictions had no clearly defined priorities when shaping the competition policy and setting its objectives. In the period of the Great Depression, in order to mitigate the consequences of a worldwide economic downturn for the economy, the US were benevolent to certain forms of agreements between companies, even though these agreements represented the most severe violation of competition, such as price fixing. For similar reasons, the European Commission tolerated the so-called "crisis cartels" at specific moments.

While the historical evidence undoubtedly shows that market forces, when left to themselves, do not always produce the best results in terms of market structures, the view that economic efficiency should be the core function of the competition policy prevails in modern industrial organization. Economic efficiency has often been viewed and assessed in terms of the three mutually compatible concepts of efficiency allocative, productive and dynamic - in relation to which the objectives and effects of the competition policy are observed. 
In a situation when the existence of the market power enables a monopolist to set prices above marginal costs, the loss of social welfare stems from allocative inefficiency. The monopolist becomes productively inefficient as well, since a lack of competitive pressure minimizes incentives to lower operational costs, and a higher cost is fully shifted forwards to consumers in the form of increased prices. The managements of these companies are not motivated to improve their business and production processes. (Liebenstein, 1966). Productive efficiency is also discussed in $M$. Motta (2002), who examines the two main arguments which suggest that a monopolistic firm is likely to be productively inefficient. The first argument is based on the so-called principal-agent models and empirical evidence of individual firms' productivity, presented by S. J. Nickell (1996) and K. M. Schmidt's (1997). The second is the so-called "Darwinian" argument, according to which competition increases industrial productivity by enabling the survival of the most efficient firms. The empirical evidence for this argument was found in G. S. Olley and A. Pakes (1996), who study the impact of technological change and gradual liberalization in the telecommunications equipment industry in the US on aggregate productivity, and in R. Disney, J. Haskel and Y. Heden (2000), who analyze the relative importance of external restructuring in the entry-and-exit form in explaining productivity growth.

Unlike the two static concepts of efficiency, whose main focus is on the existing production capacities, the third concept of efficiency refers to the ability of market participants to invest in new technologies. Under normal circumstances, competition forces businesses to innovate their production processes, introduce new technology and new products so as to improve their competitiveness. However, if research and development costs are high, as in the pharmaceutical industry, possessing a certain market power might have a positive effect on innovation. This "trade-off" between competition and innovation has been captured by a number of theoretical models. .

Market competition fosters the entrepreneurial initiative by creating incentives to innovate and, in the long-term, promotes economic efficiency, technological progress and economic growth and development. In the past, a number of countries, particularly developing ones, held the view that competition leads to the excess capacity and diseconomies of scale, and most of them lived in the fear of weakening the position of national champions in global trade. The main idea for this type of the industrial policy, as explained in M. Richardson and S. Knowles (1999), is that by limiting the number of firms in the market, the government can more easily implement some policy objectives, such as an increase in the share of tradable goods in industrial production. Simultaneously, a high concentration enables firms to obtain a high profit, and in this way the government provides high incentives to firms so as to pursue its industrial policy objectives. Therefore, M. Richardson and S. Knowles (1999) conclude that a combination of the competition policy and the industrial policy that controls a number of firms in the market was pursued by some developing countries. According to A. Amsden and A. Singh (1994) and A. Singh (2002) these countries were searching for the optimal level of competition in order to promote dynamic efficiency.

The illustration of the previous approach could be found in Japan's competition policy between 1950 and 1973, when Japan was in the position of a developing country according to A. Singh and R. Dhumale (2001). In that period, the industrial policy was more important for than government than the competition policy, and mergers between large firms in some strategic industries were encouraged by the idea that high savings and investment rates could only be achieved by big companies. A. Amsden and A. Singh (1994) explain that the optimal mix of competition and cooperation depended on the phase an industry found itself in. In young industries, competition was suppressed; in the phase of technological maturity, competition was encouraged, whereas in the declining phase, it was discouraged again. This policy brought about the high rates of economic growth and the paradoxical result was that even though the industrial policy dominated, the level of concentration in the industry declined due to the entry and larger production of small companies. In this case, economic growth reduced concentration. 
The same policy was applied in South Korea and also resulted in high growth rates. B. Song (1994) claims that the share of the 3 biggest firms in industrial production in South Korea was $62 \%$, whereas the same measure for the US economy was 3 times lower. However, economic growth did not result in a decline in concentration since growth was mainly governed by the higher production of big firms.

Such concerns have faded away over the last decades as economies have become aware of the fact that exposure to competition is the best way to strengthen the capacity of individual business entities and the entire industries in order to successfully compete in the international market.

The stagnation of the Japanese economy since 1994 has revealed that, after the first stage of development, the industrial policy must be subordinated to the competition policy. This is the line of the reasoning of D. Açemoglu, P. Aghion and F. Zilibotti (2003), who claim that high saving rates and factor accumulation are important for less and mid-developed countries, in which limited competition can be beneficial for their economic growth. When a country becomes developed, however, the growth potential of factor accumulation diminishes. In that stage, the economy is based on knowledge and sophisticated innovations require more competition.

In some developing countries, high concentration is a consequence of the dominant position of stateowned enterprises, rent seeking behavior by private companies, and high barriers to entry (Parker \& Kirkpatrick, 2004). High concentration also provides high incentives to collude. Collusion may also include local authorities and the companies with the dominant position in the local market in the form of administratively imposed barriers to entry. In this case, high concentration represents an obstacle for economic development.

The rest of the paper is organized as follows: in the second part, a brief review of the theoretical and empirical papers that deal with the impact of the competition policy on economic development is provided. In the third part, the methodology for choosing the sample of the countries for our empirical analysis is explained. In the fourth part, an explanation for the choice of the independent variables and their behavior in developing countries is explained. In the main part of the paper, the hypothesis that there is a positive impact of the effective application of the competition policy on the economic development of developing countries is tested. The ultimate part of the paper is reserved for the concluding remarks.

The theoretical literature that deals with the impact of the competition policy on economic growth suggests that competition can boost or dampen economic growth, whereas the empirical literature mainly finds a positive influence of competition on economic growth. In the theoretical literature, the impact of the competition policy is measured through its impact on innovation, whereas innovation, on the other hand, is the most important factor of economic growth.

The negative effect of competition on innovation is described in P. Aghion and R. Griffith (2008) in Hoteling's model, where a higher level of competition is represented by a reduced transport cost. Higher competition reduces a firm's profit and incentive to innovate. The same conclusion is obtained in the Dixit-Stiglitz monopolistic competition model, where higher-level competition is represented as a higher substitutability between products. Yet another possibility is presented in the Schumpeterian qualityladder model of P. Aghion and P. Howitt (1998), where property rights protection is beneficial for economic growth, and higher-level competition adversely affects economic growth through the innovator's lower profit.

According to P. Aghion and R. Griffith (2008), the positive effect of competition on innovation is explained by the rent dissipation effect in a market with a monopolist and a potential entrant. An incumbent can deter entry and retain a monopoly profit by investing in innovation. Otherwise, he has a duopoly profit. On the other hand, the entrant's profit is 0 if he stays out of the market, and he obtains a duopoly profit if he enters. Rent dissipation exists if the difference between the monopoly and duopoly profits is greater than the duopoly profit, which means that the incumbent is more motivated to innovate than the 
entrant is. An alternative explanation is provided in the model of vertical differentiation, where firms have different costs. Low-cost firms have a higher market share and this will motivate the entry of new low-cost firms. Moreover, bigger competition will induce highcost firms to innovate the production process in order to become low-cost firms.

There are some methodological problems identified by P. Aghion and R. Griffith (2008) in the relationship between a firm's size and innovation. The first issue is that a firm's size is correlated with its age, and that older firms possibly innovate more. The second issue is a reverse causality, meaning that the firms which innovate gain a market share, and a firm's size is a consequence of its innovative efforts. The last aspect implies that even if larger firms innovate more, there are fewer firms in the market and the effect on aggregate innovation is ambiguous.

An interesting approach in which the intensity of competition and innovation are mediated by asymmetric information is provided by P. Aghion, M. Dewatripont and P. Rey (1999). They assume that firms can have two possible forms of behavior: profit maximizing and conservative behavior. Under the profit maximizing assumption, competition reduces benefits from $R \& D$ for an individual firm and the overall amount of research in the industry. Therefore, under this assumption, higher-level competition reduces the endogenous growth rate. Under the assumption of conservative behavior, firms have the private costs of introducing innovation and their motivation is to delay the introduction of new technology until the very last moment before the old technology has become useless. Higher-level competition reduces the lifecycle of technologies, which means that firms will introduce new technologies earlier, in which case higher-level competition leads to a higher endogenous rate of economic growth. Firms' behavior can be made endogenous in the model when it is related to the size of agency problems between their managers and their owners. If agency problems are at a low level, firms maximize their profits, whereas if agency problems are at a high-level, firms adopt conservative behavior. This perspective offers an important recommendation for developing economies where agency problems are at a higher-level than in developed economies. In this case, higher-level competition is beneficial for economic growth.

Concerning the empirical relationship between competition and innovation, S. J. Nickell (1996) measures innovation with the total factor productivity (TFP) and finds that the growth rate of the TFP is higher in more competitive industries. The same conclusion is drawn by R. Blundell, R. Griffith and J. Van Reenen (1999), who find a higher rate of innovation in more competitive industries. By using microdata, G. R. Clarke (2011) finds that the countries with stricter competition laws have more innovations, whereas a higher-level price competition between firms reduces innovations.

The impact of the competition policy on economic development is discussed by P. Rey (1997). In developing countries, market concentration is high in some industries with high barriers to entry, implying that an appropriate merger control and an anti-collusion policy are the important elements of economic development. The underlying assumption is that high concentration does not increase dynamic efficiency.

The second aspect is related to predatory behavior, when a dominant firm in the market can initiate a price war and reduce a small firm's cash flow and increase the interest rate for a small firm's new credits. Due to the fact that financing opportunities are scarcer in developing countries and the information asymmetry is higher in the credit market, predatory behavior is a more important issue in developing than in developed countries. Therefore, the competition policy that prevents predatory behavior is beneficial for economic development.

In the empirical literature related to the impact of the competition policy on economic development, the choice of the variable that measures the competition policy and its effectiveness is the key issue. One possible measure is the Antitrust Law Index (ALI) that consists of several sub-indices. The first considers the sanctions that the competition authorities may impose, such as fines or imprisonment. The second 
relates to the merger policy. The third dimension covers collusive agreements, whereas the last one covers the restrictions of trade.

In the literature, there are also alternative approaches to the measuring of the existence of the competition policy. The first is the binary approach that uses a variable with the value 1 if a certain competition law is adopted, and the value 0 in other cases. The second approach suggests that input measures, such as the budget of the competition commission, or output variables, such as the number of the investigated cases or the number of appeals in the court against the competition commission's decisions, should be used. In order to control the size of the economy, the commission's budget should be calculated per staff or as a share of the GDP.

M. W. Nicholson (2008) shows that the Antitrust Law Index (ALI) is not an appropriate measure of the effectiveness of the policy. The variable that captures the effectiveness of the policy application is published by the World Economic Forum (WEF) and is calculated based on business leaders' opinions about the effectiveness of the competition policy. The paradox identified by M. W. Nicholson (2008) is that the ALI is the highest for transitional economies, but in these countries the laws are not accompanied by an effective application. This claim is supported by the fact that the correlation between the WEF index and the ALI is $-0,198$ indicating that the countries that have formally stricter laws have a less effective application in practice.

The impact of the competition policy on economic development can be assessed in a three-stage procedure, the idea of which came from M. Krakowski (2005). In the first stage, the effective application of the competition policy based on the WEF survey is the dependent variable, whereas the independent variables are the existence of the competition policy, the experience of the competition commission and the government's effectiveness in the general policy application. The results reveal that the variables for the competition commission's experience and the government's experience in the general policy application are significant. In the second stage, the intensity of competition based on the WEF survey is the dependent variable. Concerning the independent variables, the results reveal that the effectiveness of the competition policy and the GNP are significant, whereas the variables of external protection (tariffs, quotas and non-tariff barriers) are not significant. In the last stage, the GNP per capita is the dependent variable, while the intensity of competition is the independent variable. The results show that the economies with a higher level of competition have a higher level of economic development.

The empirical analysis of the implementation of the competition policy in transition economies is studied by M. A. Dutz and M. Vagliasindi (2000). They measure the implementation of the competition policy by applying three dimensions: enforcement, competition advocacy and institutional effectiveness.

Enforcement measures the effective application of the competition policy against firms. It consists of sub-dimensions, such as the abuse of the dominant position, cartels and mergers. Competition advocacy concerns a large set of the different economic policies that interact with the competition policy.

Institutional effectiveness is measured by the independence and transparency of the competition commission. The sample includes 26 transitional countries in Central and Eastern Europe, as well as some post-Soviet countries. The descriptive statistics reveal that the countries that have first adopted a competition policy, namely the Baltic States and Romania, lead in the implementation of the competition policy. Regression suggests that law enforcement and institutional effectiveness have a significant impact on the intensity of competition, whereas the impact of competition advocacy is not significant.

The paper that analyzes the impact of the competition policy on the GDP growth in developing and developed countries in the Solow growth model framework is T. C. Ma's (2011). The presence and scope of the competition policy is captured by the SCOPE variable that is defined in the paper by K. N. Hylton and F. Deng (2007). The overall effectiveness of the government's application of policies, not only of the competition policy, is captured by the 
EFFICIENCY variable that is defined in the paper by D. Kaufmann, A. Kraay and M. Mastruzzi (2009). The results show that the SCOPE variable is not significant and the formal existence of the competition law cannot influence economic growth. The interacting variable of SCOPE x EFFICIENCY is named EFFLAW. For poor countries, the coefficient for this variable is 0.04 and is significant, whereas for rich countries the coefficient is 0.064 and is also significant. Therefore, the competition law must be complemented with the effective enforcement of this policy.

\section{SAMPLING METHODOLOGY}

The term "developing country" is commonly used to indicate the country that has a relatively low living standard, the underdeveloped industry and a lower level of the overall wellbeing relative to more (economically) developed countries. Various institutions use different thresholds of material and non-material wealth to classify individual jurisdictions in certain categories of development, and it is extremely difficult to accurately answer the question of how much a country should (or should not) be "rich" to be considered as a developing country. Even among developing countries, one might encounter evident differences in the level of economic and social development. These issues have brought about a widespread debate on the use of the term developing country in recent years, and have ultimately encouraged international organizations to soften their approaches or even cease to distinguish between "developed" and "developing" countries in the presentation of their data.

The GDP or income per capita is usually considered as the initial criterion for classifying countries in the different stages of development. For both operational and analytical purposes, the World Bank classifies countries according to their gross national income per capita into four income groups: low income countries, lower and upper middle income countries and high income countries. Other institutions use slightly different classification schemes. The International Monetary Fund, for example, applies a flexible classification system by taking into account per capita income, the diversification of exports and the degree of integration into the global financial system. According to these three criteria, countries are classified into advanced economies, on the one hand, and emerging market and developing economies, on the other.

Until 2004, the IMF had clustered all the Central and Eastern European countries, including the former Soviet Union countries in Central Asia and Mongolia, into countries in transition, whereas today, they all belong to developing countries. The UNDP broadly classifies all countries into three categories: developed economies, economies in transition and developing countries. Certain economies within developing and transition countries are further classified as fuelexporting countries, whereas a fair percentage of developing countries fit into the group of the least developed countries. Developing countries are also divided into landlocked and small island developing countries.

When deciding upon which countries to include in our sample, we commenced with the WB List of Economies from December 2016. Initially, we included all of the lower and upper middle income countries, namely 70 of them in total. In order to avoid extreme discrepancies in terms of income, we decided to exclude low-income countries from our analysis, despite the fact that until recently they have also been considered as developing countries. Further research showed that 60 out of the 70 initially considered countries had competition legislation in force, so the final sample was composed of 60 countries. This is a considerable improvement compared to 1990, when only 16 developing countries had a formal competition policy according to A. Singh (2002), and were assisted by the WTO and other international institutions to adopt competition laws in the period that followed.

Although the countries in the sample constitute a heterogeneous group, the results of the research will be of great importance since the testing of the initial hypothesis will provide an answer to the importance of the effective implementation of the competition policy for economic development. 


\section{INDICATORS OF THE EFFECTIVE APPLICATION OF THE COMPETITION POLICY AND ECONOMIC DEVELOPMENT}

Before testing the initial hypothesis set in this research study, we analyzed the individual indicators that would be used as the variables in the regression model. As the indicator of the effective application of the competition policy, we used the country scores provided by the World Economic Forum (WEF, 2016). Since its establishment, the WEF has created a number of indices to measure and compare the competitiveness of national economies. The indicator that has been in use since 2005 is called the Global Competitiveness Index (GCI), and it assumes that, in today's globalized economy, there are a number of the factors that explain the competitiveness of national economies. Another important feature of the GCI is that all the factors of competitiveness are grouped into 12 categories, i.e. the 12 pillars of competitiveness.

In order to create a global competitiveness index, the WEF uses a total of 114 competitiveness factors. The data used in the research study were obtained in two ways: by the direct measurement (the quantifiable data), obtained from the relevant statistics and international institutions, and the executive opinion surveys, where data are obtained by interviewing the representatives of the business community. The WEF includes the majority of the factors that are key to economic growth and development: institutions, macroeconomic factors, the infrastructure, education, technology and so on. Every year, the WEF conducts a survey which covers a significant number of countries. Respondents are business leaders who evaluate the effectiveness of the competition policy in their country. The effectiveness of the competition policy of each country is given a score, ranging from 1 to 7 . The score 1 means that the competition policy is weak and ineffective, while the score 7 means that there is an effective protection of competition in that country. One of the shortcomings of the GCI, as well as of the individual factors, is the fact that the indices mostly rely on the data obtained from different surveys, which, to some extent, makes the obtained estimates biased and may affect the research outcome.
However, for the purpose of this study, the data to be used can be considered as relevant.

The first variable that we present is the average GDP per capita, which is the dependent variable in our regression, the indicator in our analysis being the GDP per capita. The GDP per capita is used as an indicator of the economic development of the observed countries in order to test the hypothesis. The GPD per capita for the year 2015 for the observed countries is shown in Figure 1.

The average GDP per capita for the observed countries amounts to about 5000 USD. Argentina, Panama and Costa Rica feature the very high levels of the GDP per capita compared to the remaining sample. We will neutralize the negative impact of these extreme values on the estimated regression model by introducing a dummy variable. Such a high level of the development of Argentina and the other two countries in Central America is explained by A. Saravia, C. Machicado and F. Rioja (2014), who explain it by alleging high productivity in agriculture, which enabled these countries to relatively early commence the process of industrialization.

The comparative analysis of the indicators of the effective implementation of the competition policy is provided in Figure 2.

Figure 2 shows that the average score for the countries in the sample is about 3.5. South Africa is the toprated country, whereas the worst performing country in terms of the effective application of the competition policy is Venezuela. South Africa adopted its Competition Act in 1999, when it recognized the necessity for a strong competition policy due to the high level of concentration in the South African economy (Roberts, 2004).

In addition to the previously presented independent variables, on which we base the hypothesis testing, we included in our analysis certain other independent variables: the consumer price index, the exports of goods and services (\% of the GDP), the population growth, start-up procedures to register a business (the number of days) and the unemployment rate (\% of the total workforce). All of the indicators are graphically presented below. 


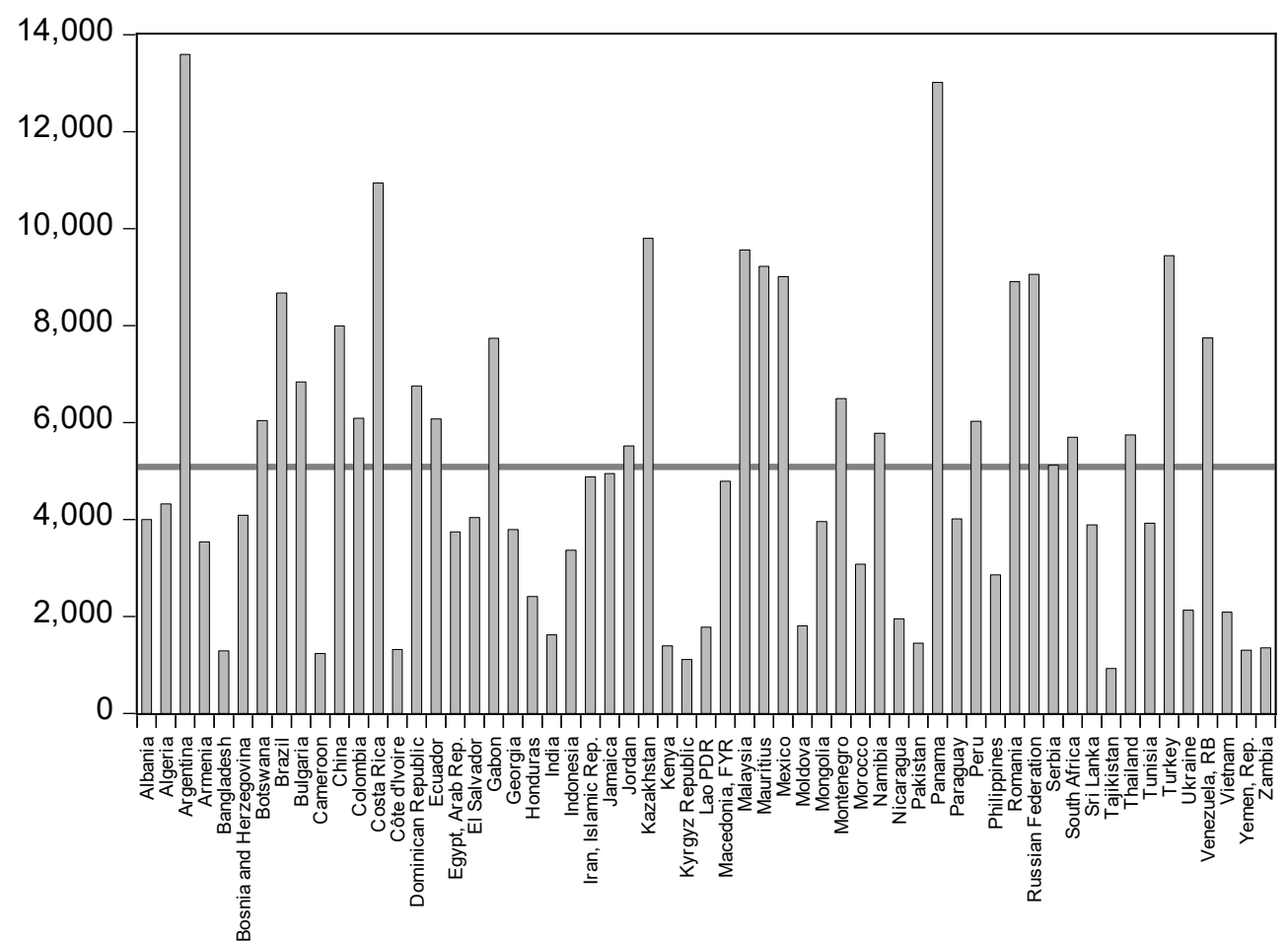

Figure 1 The GDP per capita in 2015 (USD)

Source: World Bank

The highest consumer price index, as the proxy of inflation, was observed in the Russian Federation and Iran, whereas Thailand, Jordan and Romania had the lowest (negative) consumer price indices in 2015. The majority of the countries in the sample that have a low level of inflation pursue the policy of inflation targeting (Volz, 2015).

The exports of goods and services of the countries in the sample account for about $35 \%$ of the GDP on average. The highest share of exports in the GDP was recorded in Vietnam, above $80 \%$, whereas Yemen, Tajikistan and Pakistan are the least dependent upon exports (around 10\% of the GDP).

The next explanatory variable is the population growth rate. The average population growth rate among the selected countries amounts to about $1.2 \%$ (Figure 3). The highest rate in 2015 was recorded in Zambia and Kenya, whereas Bulgaria, the Republic of Serbia and Romania, among others, faced negative population growth. The negative growth rate is an obstacle for economic development since the ageing of a population diverts resources from investments in economic development to the healthcare system and pensions (Teixeira, Renuga Nagarajan \& Silva, 2016). An interesting analysis of the relationship between pollution, fertility and the GDP per capita is provided by D. Varvarigos and I. Z. Zakaria (2017).

The average number of the days needed to start up a business in the selected countries is around 8 . The best performing countries in terms of the easiness of registering a business are the FYR of Macedonia and Jamaica, whereas the worst rated are Venezuela and the Philippines.

The highest unemployment rates among the countries in the sample were observed in the FYR of Macedonia, Bosnia and Herzegovina and South Africa (above 20\% of the total workforce), whereas on the other hand, Thailand faces the unemployment rate of close to 0 (Figure 4). 


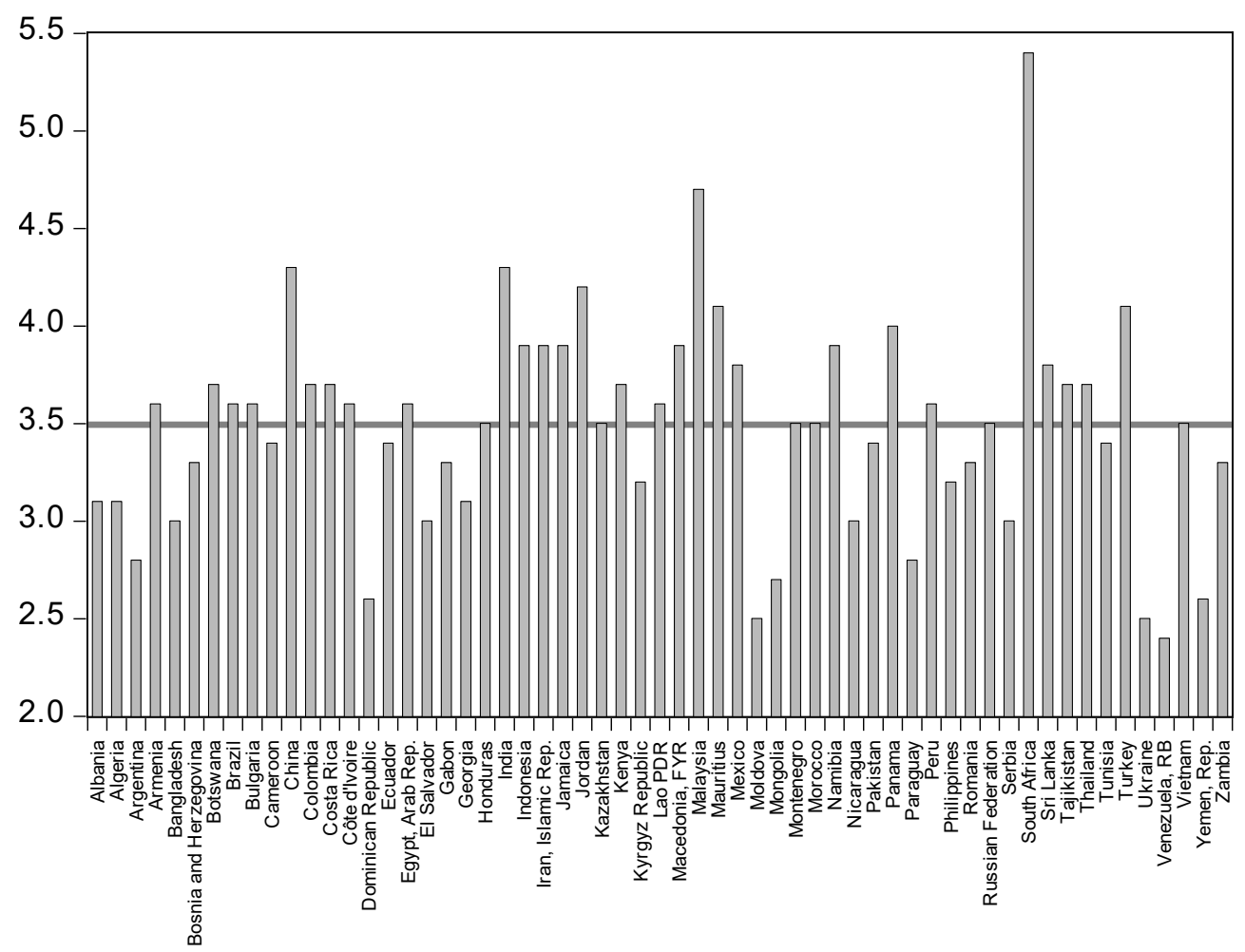

Figure 2 The effective implementation of the competition policy

Source: WEF, 2016

According to H. Feldmann (2008), the unemployment rate in developing economies could be reduced by more cooperative industrial relations that reduce companies' turnover rate and consequently the unemployment rate as well.

\section{THE IMPACT OF THE COMPETITION POLICY ON ECONOMIC DEVELOPMENT}

In this part of the research study, the main hypothesis that there is a positive impact of the effective application of the competition policy on the economic development of developing countries will be tested. In order to test the hypothesis, we will use the previously described and analysed indicators. By using the regression analysis, we estimated the linear model of the following form:
$G D P_{-} p c=\beta_{0}+\beta_{1} W E F+\beta_{2} C P I+\beta_{3} E X P+\beta_{4} P O P G$

$+\beta_{5} S T A R T U P+\beta_{6} U N E M P L O Y M E N T+\varepsilon$

where the dependent variable measuring the development level is the GDP per capita. The other previously mentioned indicators are used as the independent variables: the WEF (the effective competition policy), the CPI (the inflation rate), the EXP (the share of export in the GDP), STARTUP (the procedures to register a business), and UNEMPLOYMENT (the unemployment rate). In the initial model, the CPI, EXP and STARTUP variables are not statistically significant, and are excluded from a further analysis. The initial model is presented in the appendix.

After the exclusion of the variables that were not significant, we estimated the reduced form of the model. In the second regression, we added a dummy 


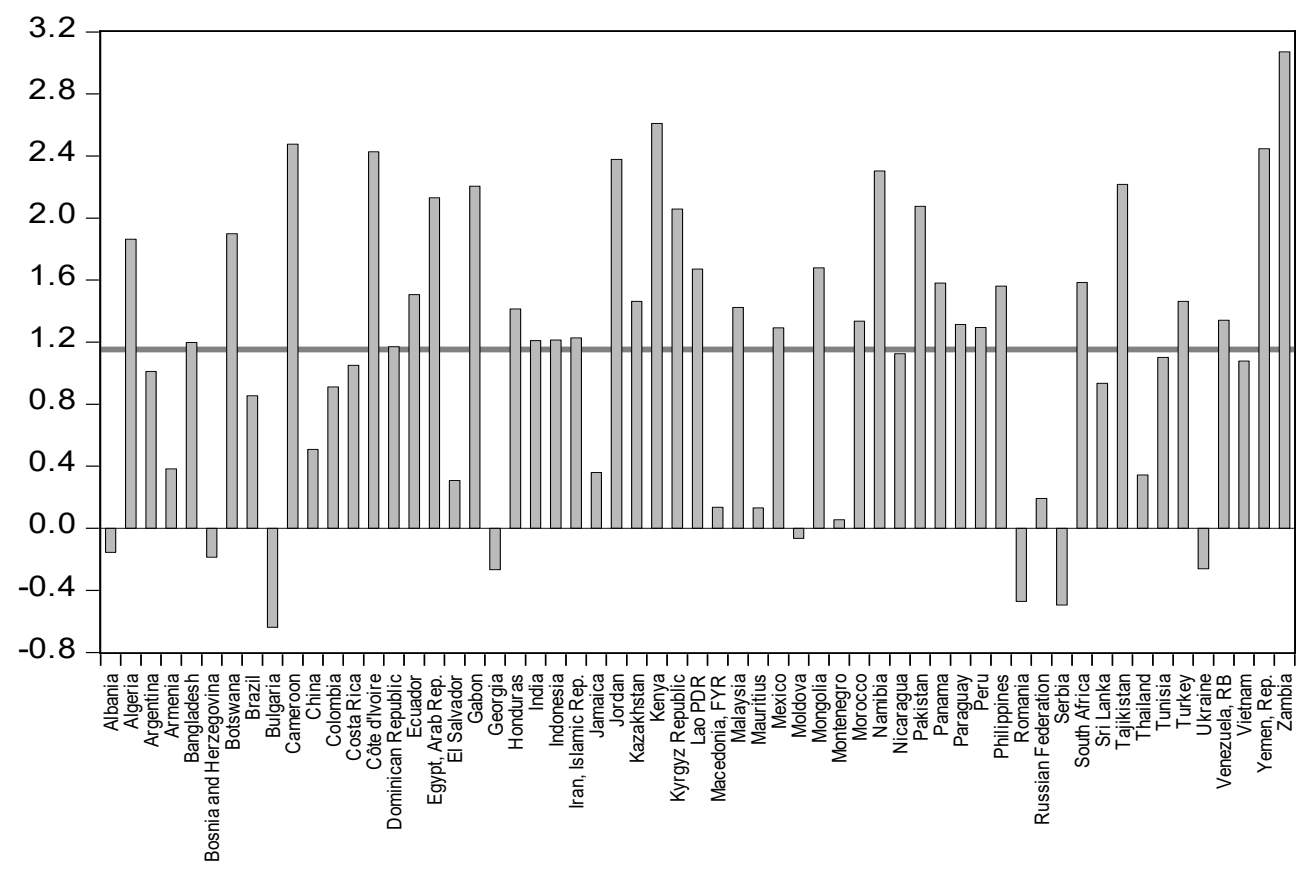

Figure 3 The population growth 2015

Source: World Bank

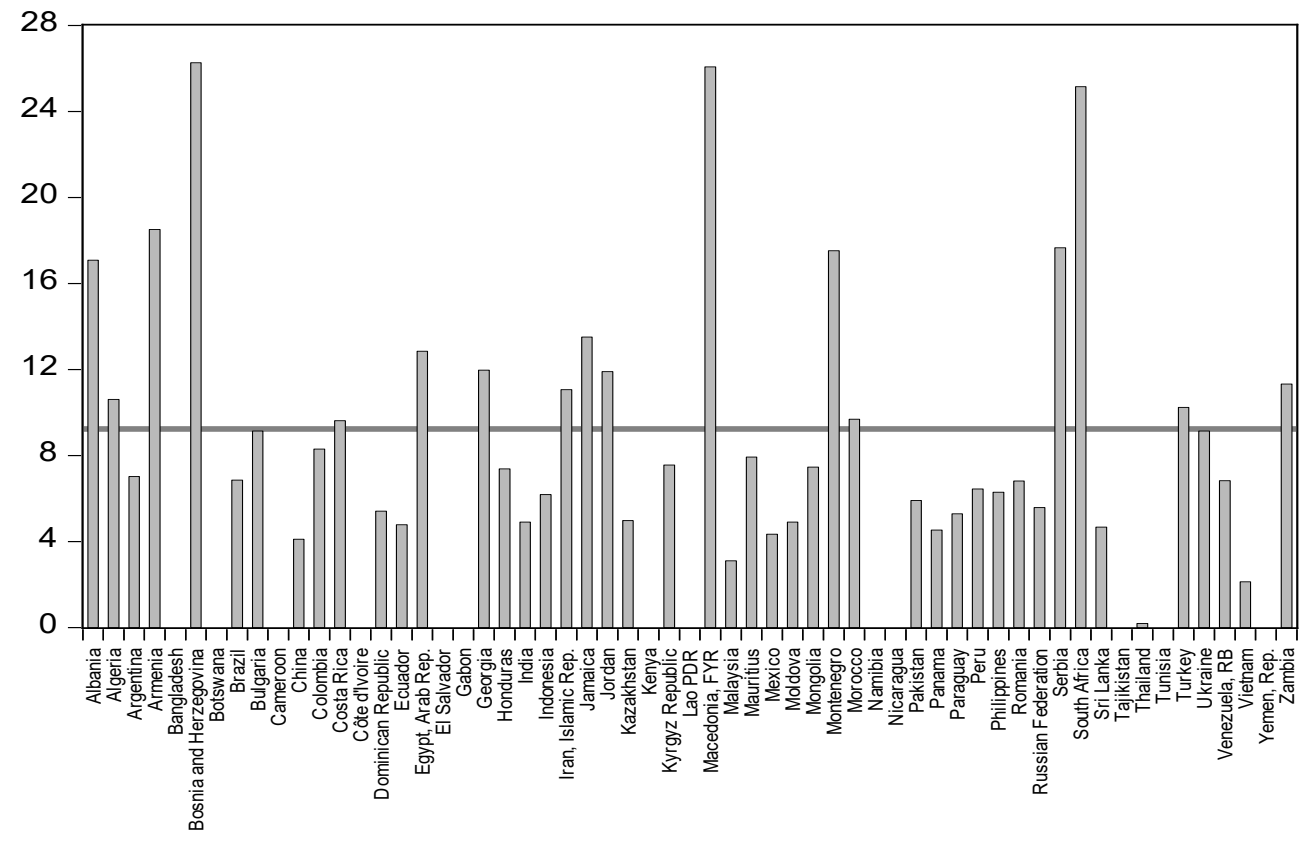

Figure 4 The unemployment rate (\% of the total workforce) 2015

Source: World Bank 
variable which eliminated the extremely high values of the GDP per capita for three countries: Argentina, Costa Rica and Panama. The dummy variable took the value 1 for these countries, and 0 in other cases. The estimated model showed that all the coefficients were statistically significant at the $10 \%$ significance level, whereas the coefficient for the Unemployment Rate was not statistically significant at the 5\% level. The last result triggered a more detailed analysis of the residuals of the estimated model, by which it was determined that the residual had the highest absolute value for India. A further analysis of the indicators for this country revealed that the GDP per capita and the unemployment rate were inconsistent. In other words, the low level of the unemployment rate should be coupled with a high GDP per capita, and vice versa. Since this was not the case here, we added yet another dummy variable that had the value 1 for India, and the value 0 for the other countries. By introducing the two dummy variables, we built the final model that was used for testing the main hypothesis:

$$
\begin{aligned}
& G D P_{-} p c=\beta_{0}+\beta_{1} W E F+\beta_{2} C P I+\beta_{2} P O P G \\
& +\beta_{3} U N E M P L O Y M E N T+\beta_{4} D U M+\beta_{4} D U M_{2}+\varepsilon
\end{aligned}
$$

The estimated model shows that all of the variables are statistically significant, including the two dummy variables at the $5 \%$ significance level.

In order to test the validity of the model, additional econometric tests are needed. First, the existence of a residual autocorrelation should be determined. The value of the Durbin-Watson statistics is 2.25 , based on which the hypothesis of the existence of the firstorder autocorrelation can be rejected.

The same conclusion is reached from the correlogram analysis. After testing for autocorrelation, we test for the residual normality. The value of the JarqueBera statistics is 1.06 , with the $p$ value 0.59 , which means that at the significance level $\alpha=0.05$ we cannot reject the hypothesis that residuals have a normal distribution.

The test of the heteroscedasticity of the residuals was performed by applying the White test. The values of the $\mathrm{F}$ and $\chi^{2}$ statistics are 1.35 and 16.29 , respectively, with the corresponding $p$ values of 0.23 and 0.23 , respectively, implying that at the $\alpha=0,05$ level of statistical significance we cannot reject the hypothesis of the absence of the heteroscedasticity and regularity of the model's linear form. From the correlation matrix of the independent variables, it can be inferred that there is no multicollinearity in the model.

Table 1 The estimated model

\begin{tabular}{l|llll}
\hline Variable & Coeff. & $\begin{array}{l}\text { Std. } \\
\text { Error }\end{array}$ & t-Statistic & Prob. \\
C & \multicolumn{5}{|l}{ 818.9172 } & 2055.959 & 0.398314 & 0.6925 \\
\hline WEF_VALUE & 1909.741 & 599.4599 & 3.185769 & 0.0028 \\
POPG & -1011.617 & 412.9202 & -2.449910 & 0.0188 \\
UNEMP & -135.8814 & 58.85549 & -2.308729 & 0.0262 \\
DUM & 7196.002 & 1334.294 & 5.393118 & 0.0000 \\
DUM2 & -5524.342 & 2315.986 & -2.385309 & 0.0219 \\
\hline R-squared & 0.546669 & Mean dependent var & 5661.415 \\
Adj. R-sq. & 0.490002 & S.D. dependent var & 3103.315 \\
$\begin{array}{l}\text { S.E. of } \\
\text { regression }\end{array}$ & 2216.206 & Akaike info criterion & 18.36609 \\
$\begin{array}{l}\text { Sum squ. } \\
\text { Resid }\end{array}$ & $1.96 E+08$ & Schwarz criterion & 18.60461 \\
Log likelihood & -416.4200 & Hannan-Quinn criter. & 18.45544 \\
$\begin{array}{l}\text { F-statistic } \\
\text { Prob }\end{array}$ & 9.647135 & Durbin-Watson stat & 2.257815 \\
(F-statistic) & 0.000004 & & & \\
\hline
\end{tabular}

Source: The results of the estimated model from Eviews.

The most important conclusion of the previous regression analysis is that there is a positive impact of the effective application of the competition policy on the economic development of developing countries at the $5 \%$ significance level. Moreover, the whole regression is statistically significant and can be accepted with the equal level of significance. The determination coefficient is 0.55 , which means that the independent variables account for $55 \%$ of the variations of the GDP per capita for the countries in our sample. 


\section{CONCLUSION}

The competition policy has the role of protecting and strengthening market competition, which, in itself, provides economically efficient outcomes. Nevertheless, increasing economic efficiency has not always been the main or the sole aim of the competition policy. Throughout history, certain economies have given greater importance to the specific socio-political functions of the competition policy, whereas other countries' aspirations to creating national champions have prevailed over the need for the efficient protection of competition. Such attempts have not yielded the expected results, especially not so in the long-run. Therefore, the main objective of this paper is to establish the positive relationship between the competition policy and economic development.

The choice of the variable that best captures the effectiveness of the competition policy has proved to be the key issue related to measuring the impact of the competition policy on economic development. In the existing empirical literature, various simple and composite indicators of the competition policy have been used for that purpose. The most important conclusion to draw from these attempts intended for the estimation of the impact of the competition policy is that the mere existence of competition legislation is insufficient and must be complemented with its effective enforcement. This is the approach that we have followed in our paper, where we have chosen the WEF indicator as the proxy for the effective application of the competition policy.

Nevertheless, the limitation of the previous analysis is that the WEF indicator is based on business leaders' subjective opinions about the effectiveness of the competition policy. It would be better to use a certain composite index that would contain objective measures, such as the number of the cases successfully resolved by the Competition Commission, or the number of appeals against the Competition Commission's decisions in the court. However, these data are not available for all countries, and previous studies were faced with the same obstacle.
The choice of the other independent variables was made with the objective to avoid multicollinearity in the model. Some of these variables proved not to be statistically significant in the initial model estimation, for which reason we estimated the model by excluding these variables. Needless to say, there is room for the inclusion of other independent variables so as to increase the explanatory power of our regression.

The main contribution of our paper rests on the identified positive relationship between the effective application of the competition policy and the economic development of developing countries. The results presented in this paper are based on the sample of the 60 developing countries that currently have competition legislation in force. The initial hypothesis of this research was confirmed within the linear regression framework, where the WEF variable is highly statistically significant. The additional econometric tests confirmed the validity of the model.

Based on these results, it can be concluded that the effective implementation of the competition policy has a positive impact on the economic development of developing countries. For this reason, the entities responsible for the implementation of the economic policy in developing countries are recommended to pay special attention to the implementation of the competition policy.

The additional implication of this research study of ours is that the models of economic growth may miss one important variable: the effective application of the competition policy. Within the Solow model framework, the residual may not only capture technical progress, but also the factor that we ourselves identified. However, making the overall effect of the competition policy endogenous in the growth model, not just its effect on innovations, which was the main idea of the previous attempts, would be a challenging task to do.

This paper opens many interesting issues for further research. One possible topic for future research could be the assessment of the impact of the competition policy on the economic development of the specific sectors of the economy, which would enable policy-makers to better understand which 
sectors require further supervision and control of the level of competition. The second issue is related to methodological aspects of the model specification, its functional form, and the group of the observed variables.

\section{REFERENCES}

Açemoglu, D., Aghion, P., \& Zilibotti, F. (2006). Distance to frontier, selection, and economic growth. Journal of the European Economic Association, 4(1), 37-74. doi.org/10.1162/ jeea.2006.4.1.37

Aghion, P., \& Howitt, P. (1998). Market structure and the growth process. Review of Economic Dynamics, 1(1), 276-305. doi.org/10.1006/redy.1997.0007

Aghion, P., Dewatripont, M., \& Rey, P. (1999). Competition, financial discipline and growth. The Review of Economic Studies, 66(4), 825-852. doi.org/10.1111/1467-937X.00110

Aghion, P., \& Griffith, R. (2008). Competition and Growth: Reconciling Theory and Evidence. Cambridge, US: MIT press.

Amsden, A., \& Singh, A. (1994): The optimal degree of competition and dynamic efficiency in Japan and Korea. European Economic Review, 38(3-4), 941-951. doi. org/10.1016/0014-2921(94)90130-9

Blundell, R., Griffith, R., \& Van Reenen, J. (1999). Market share, market value and innovation in a panel of British manufacturing firms. The Review of Economic Studies, 66(3), 529-554. doi.org/10.1111/1467-937X.00097

Clarke, G. R. (2011). Competition policy and innovation in developing countries: Empirical evidence. International Journal of Economics and Finance, 3(3), 38-49. doi:10.5539/ijef. v3n3p38

Disney, R., Haskel, J., \& Heden, Y. (2000). Restructuring and productivity growth in the UK. Research Paper 2000/13, University of Nottingham, UK: Centre for Research on Globalization and Labour Markets, School of Economics.

Dutz, M. A., \& Vagliasindi, M. (2000). Competition policy implementation in transition economies: An empirical assessment. European Economic Review, 44(4), 762-772. doi. org/10.1016/S0014-2921(99)00060-4
Feldmann, H. (2009). The quality of industrial relations and unemployment in developing countries. Review of Development Economics, 13(1), 56-69. doi.org/10.1111/ j.14679361.2008.00459.x

Hylton, K. N., \& Deng, F. (2007). Antitrust around the World: An empirical analysis of the scope of competition laws and their effects. Antitrust Law Journal, 74(2), 271-341.

Kaufmann, D., Kraay, A., \& Mastruzzi, M. (2009). Governance matters viii: Aggregate and individual governance indicators, 1996-2008. Policy Research Working Paper, World Bank.

Krakowski, M. (2005). Competition policy works: The effect of competition policy on the intensity of competition - an international cross-country comparison. HWWA Discussion Paper, Hamburg Institute of International Economics.

Liebenstein, H. (1966). Allocative efficiency vs X-Inefficiency. American Economic Review, 56(3), 392-415

Ma, T. C. (2011). The effect of competition law enforcement on economic growth. Journal of Competition Law and Economics, 7(2), 301-334. doi.org/10.1093/joclec/nhq032

Motta, M. (2002). Competition Policy: Theory and Practice. Cambridge, NY: Cambridge University Press.

Nicholson, M. W. (2008). An antitrust law index for empirical analysis of international competition policy. Journal of Competition Law and Economics, 4(4), 1009-1029. doi. org/10.1093/joclec/nhn009

Nickell, S. J. (1996). Competition and corporate performance. Journal of Political Economy, 104(4), 724-746.

Olley, G. S., \& Pakes, A. (1996). The dynamics of productivity in the telecommunications equipment industry. Econometrica, 64(6), 1263-1297. doi:10.2307/2171831

Parker, D., \& Kirkpatrick, K. (2004). Economic regulation in developing countries: A framework for critical analysis. In P. Cook, K. Kirkpatrick, M. Minogue, \& D. Parker (Eds.). Leading Issues in Competition, Regulation and Development (pp. 92-113). Edward Elgar Publishing.

Rey, P. (1997). Competition policy and economic development. IDEI-Toulouse, September.

Richardson, M., \& Knowles, S. (1999). On the Use of competition policy to enhance the effectiveness of industrial policy. Review of Development Economics, 3(1), 5865. doi.org/10.1111/1467-9361.00051 
Roberts, S. (2004). The role for competition policy in economic development: The South African experience. Development Southern Africa, 21(1), 227-243. doi:10.1080/0376835042000181499

Saravia, A., Machicado, C., \& Rioja, F. (2014). Productivity, structural change and Latin American development. Review of Development Economics, 18(3), 610-624. doi.org/10.1111/ rode.12106

Schmidt, K. M. (1997). Managerial incentives and product market competition. Review of Economic Studies, 64(2), 191213. doi:10.2307/2971709

Schumpeter, J. A. (1954). Capitalism, Socialism and Democracy. Unwin University Books, Chapter 7 - "The Process of Creative Destruction"

Singh, A. (2002). Competition and competition policy in emerging markets: International and development dimensions, ESRC centre for business research. Working paper No 246, University of Cambridge.
Singh, A., \& Dhumale, R. (2001). Competition policy, development, and developing countries. In P. Arestis, M. Baddeley, \& J. McCombie (Eds.). What Global Economic Crisis? (pp. 122-145). Londdon, UK: Palgrave Macmillan.

Song, B. (1994). The Rise of the Korean Economy. Hong Kong: Oxford, Oxford University Press.

Teixeira, A., Renuga Nagarajan, N., \& Silva, S. T. (2016). The impact of ageing and the speed of ageing on the economic growth of least developed, emerging and developed countries, 1990-2013. Review of Development Economics, 21(3), 909-934. doi.org/10.1111/rode.12294

Varvarigos, D., \& Zakaria, I. Z. (2017). Longevity, fertility and economic growth: Do environmental factors matter? Review of Development Economics, 21(1), 43-66. doi.org/10.1111/ rode.12239

Volz, U. (2015). On the future of inflation targeting in East Asia. Review of Development Economics, 19(3), 638-652. doi. org/10.1111/rode.12173

World Economic Forum - WEF. (2016). The Global Competitiveness Report 2016-2017. Geneva.

Received on $9^{\text {th }}$ April 2018, after revision, accepted for publication on $22^{\text {nd }}$ August 2018 Published online on $27^{\text {th }}$ August 2018

Sinisa Milosevic is the head of the Sector for Economic Analysis of the Serbian Commission for the Protection of Competition. He received his Ph.D at Faculty of Economics, University of Belgrade. He has published many papers in the field of the competition policy.

Dejan Trifunovic is an associate professor at the Faculty of Economics, University of Belgrade, where he received his Ph.D. He teaches the Microeconomics and Industrial Organisation undergraduate courses, as well as the Microeconomics course in the master's and doctoral studies. His scientific interest is in game theory, auctions, matching, asymmetric information and network externalities.

Jelena Popovic Markopoulos is a senior advisor in the Sector for Economic Analysis of the Serbian Commission for the Protection of Competition. She obtained her master's degree at the University of Tor Vergata, Rome, and the Faculty of Economics, University of Belgrade. She is currently at the Ph.D. studies at the Faculty of Economics in Belgrade. The competition policy is the field of her scientific interest. 


\title{
UTICAJ POLITIKE ZAŠTITE KONKURENCIJE NA EKONOMSKI RAZVOJ ZEMALJA U RAZVOJU
}

\author{
Siniša Milošević', Dejan Trifunović2* i Jelena Popović Markopoulos \\ 'Komisija za zaštitu konkurencije Republike Srbije \\ ${ }^{2}$ Ekonomski fakultet Univerziteta u Beogradu
}

\begin{abstract}
U ovom radu se razmatra uticaj efektivne primene politike zaštite konkurencije na ekonomski razvoj zemalja u razvoju. U empirijskim radovima je utvrđeno da postojanje politike zaštite konkurencije ne utiče značajno na nivo društvenog proizvoda per capita i da samo efektivna primena ove politike ima uticaj. Ovaj rad će biti zasnovan na tim rezultatima, pa ćemo koristiti indeks Svetskog ekonomskog foruma kao meru efektivne primene politike zaštite konkurencije. U radu je potvrđeno da deo varijacija u društvenom proizvodu per capita između zemalja u razvoju može da bude objašnjen efektivnom primenom politike zaštite konkurencije.
\end{abstract}

Ključne reči: zaštita konkurencije, intenzitet konkurencije, ekonomski razvoj, zemlje u razvoju

JEL Classification: L51, 012

\section{UVOD}

Predmet ovog istraživanja jeste ispitivanje uticaja politike zaštite konkurencije na ekonomski razvoj zemalja u razvoju. Iako u svetu postoji već duže od jednog veka, u pojedinim zemljama ova oblast nema dugu istoriju primene. Njena osnovna funkcija je da doprinese povećanju društvenog blagostanja i povećanju efikasnosti i produktivnosti privrede $u$ celini. Većina zemalja nastoji da formuliše strategiju održivog rasta, koja će obezbediti bolji životni

* Korespondencija: D. Trifunović, Ekonomski fakultet Univerziteta u Beogradu, Kamenička 6, 11000 Beograd, Republika Srbija; e-mail: dejan@ekof.bg.ac.rs standard. Takve okolnosti uslovile su promenu paradigme ekonomskog razvoja, tako da se zemlje u razvoju sve više okreću rešavanju unutrašnjih problema, jer je njihov uticaj na globalnom nivou ograničen.

Jedan od osnovnih unutrašnjih problema zemalja u razvoju svakako je i rešavanje pitanja politike zaštite konkurencije. Donošenje regulatornog okvira i formiranje regulatornog tela iz ove oblasti, predstavljaju uslov i za prijem u punopravno članstvo u Evropskoj uniji. Postoji obimna literatura o politici zaštite konkurencije, i u okviru nje postoje teorijski utemeljene tvrdnje da sprovođenje takve politike doprinosi ekonomskom napretku i dobrobiti celog 
društva. Postavlja se pitanje, da li se to ostvaruje u praksi, pre svega, da li to važi i za zemlje u razvoju?

Predmet istraživanja ovog rada će biti usmeren na testiranje sledeće hipoteze:

$\mathrm{H}$ : Efikasno vođenje politike zaštite konkurencije ima pozitivan uticaj na ekonomski razvoj zemalja u razvoju.

Za testiranje ove hipoteze biće formulisani indikatori efikasne primene politike zaštite konkurencije i ekonomskog razvoja.

Cilj istraživanja jeste da se pokaže da postoji pozitivan uticaj efikasno vođene politike zaštite konkurencije na ekonomski razvoj zemalja u razvoju. Pored toga, cilj je da se doprinose razumevanju značaja koji politika zaštite konkurencije ima u regulatornom okviru privrede jedne zemlje. Ukoliko se potvrdi tačnost postavljene hipoteze, zemlje u razvoju zbog procesa i promena koje se dešavaju na njihovim tržištima, trebala bi da veliku pažnju posvete upravo razvoju i sprovođenju politike zaštite konkurencije. Politika zaštite konkurencije direktno utiče na odluke pojedinačnih privrednih subjekata. $\mathrm{Na}$ taj način ona ima i indirektan uticaj na potrošače, na jednoj, odnosno, celu privredu, na drugoj strani.

Ostatak rada je organizovan na sledeći način. U drugom delu daje se kratak pregled literature, koja razmatra uticaj politike zaštite konkurencije na ekonomski razvoj. U trećem delu objašnjava se metodologija za odabir uzorka zemalja za empirijsku analizu. U sledećem, četvrtom delu objašnjava se izbor nezavisnih promenljivih i analizira njihovo ponašanje. U glavnom delu rada, testira se hipoteza da postoji pozitivan uticaj efektivne primene politike zaštite konkurencije na ekonomski razvoj zemalja u razvoju. U poslednjem delu rada sledi zaključak.

\section{PREGLED LITERATURE}

Prema hipotezi konvergencije, zemlje $u$ razvoju trebalo bi da imaju veće stope ekonomskog rasta nego razvijene zemlje. Međutim, nastavak održivog ekonomskog razvoja i konvergencije zemalja $u$ razvoju podriven je tokom globalne ekonomske krize. U takvom okruženju usporenog ekonomskog napretka na globalnom nivou, zemlje u razvoju treba da posvete više pažnje unutrašnjim pitanjima koja mogu doprineti ekonomskom rastu.

Konkurencija podstiče učesnike na tržištu da budu efikasniji i pružaju veći izbor proizvoda i usluga po nižim cenama. Istovremeno, konkurencija povećava ekonomsku efikasnost, kroz smanjenje troškova proizvodnje, tehnološki napredak i inovacije. Iako zaštita konkurencije može povećati blagostanje zbog prethodno navedenih razloga, politika zaštite konkurencije može biti, često, u sukobu sa drugim ciljevima ekonomske politike.

U prošlosti, većina zemalja nije imala jasno definisane prioritete pri oblikovanju politike zaštite konkurencije i postavljanju svojih ciljeva. U periodu velike depresije, u cilju ublažavanja posledica svetske ekonomske krize na privredu, SAD su tolerisale određene oblike sporazuma između kompanija, iako su ti sporazumi predstavljali najteže narušavanje konkurencije, kao što je fiksiranje cena. Iz sličnih razloga, Evropska komisija je u određenim trenucima tolerisala takozvane krizne kartele.

Iako istorijski dokazi nesumnjivo pokazuju da tržišne snage, prepuštene sebi, ne proizvode uvek najbolje rezultate $\mathrm{u}$ pogledu tržišnih struktura, $\mathrm{u}$ savremenoj industrijskoj organizaciji preovlađuje stav da ekonomska efikasnost treba da bude osnovna funkcija politike zaštite konkurencije. Ekonomska efikasnost se često posmatra i procenjuje kroz tri međusobno kompatibilna koncepta efikasnosti alokativna, proizvodna i dinamička - u odnosu na koje se posmatraju ciljevi i efekti politike zaštite konkurencije.

U situaciji kad postojanje tržišne moći omogućava monopolisti da odredi cenu iznad graničnog troška, gubitak društvenog blagostanja potiče od alokativne neefikasnosti. Istovremeno, monopolista postaje proizvodno neefikasan, jer nedostatak konkurentskog pritiska minimizira podsticaje za smanjenje operativnih troškova, a veći trošak se $u$ potpunosti prebacuje na potrošače u obliku povišenih 
cena. Menadžment ovih kompanija nije motivisan da poboljša svoje poslovne i proizvodne procese (Liebenstein, 1966). Proizvodnu efikasnost, takođe, razmatra M. Motta (2002), koji ispituje dva glavna argumenta koja ukazuju na to da je monopolska kompanija proizvodno neefikasna. Prvi argument zasniva se na principal-agent modelu i empirijskim dokazima o produktivnosti pojedinih preduzeća, koje su predstavili S. J. Nickell (1996) i K. M. Schmidt (1997). Drugi je takozvani Darvinistički argument, prema kome konkurencija povećava produktivnost grane, omogućujući opstanak najefikasnijih preduzeća. Empirijski dokaz za ovaj argument su predstavili G. S. Olley i A. Pakes (1996), koji proučavaju uticaj tehnoloških promena i postepene liberalizacije $u$ grani telekomunikacijske opreme u SAD na ukupnu produktivnost, kao i R. Disney, J. Haskel i Y. Heden (2000), koji analiziraju relativnu važnost spoljnog restrukturiranja grane kroz ulazak i izlazak $u$ objašnjavanju rasta produktivnosti.

Za razliku od dva statička koncepta efikasnosti, čiji je glavni fokus na postojećim proizvodnim kapacitetima, treći koncept efikasnosti odnosi se na sposobnost učesnika na tržištu da ulažu u nove tehnologije. Pod normalnim okolnostima, konkurencija podstiče preduzeća da inoviraju svoje proizvodne procese, uvode nove tehnologije i nove proizvode, kako bi poboljšali svoju konkurentnost. Međutim, ako su troškovi istraživanja i razvoja visoki, kao u farmaceutskoj industriji, posedovanje određene tržišne moći može pozitivno uticati na inovacije. Ovaj kompromis između konkurencije i inovacija obuhvaćen je većim brojem teorijskih modela.

Tržišno nadmetanje podstiče preduzetničku inicijativu stvaranjem podsticaja za inovacije i dugoročno promoviše ekonomsku efikasnost, tehnološki napredak, i ekonomski rast i razvoj. U prošlosti, određeni broj zemalja, posebno onih $\mathrm{u}$ razvoju, polazio je od pretpostavke da konkurencija dovodi do viška kapaciteta i opadajućih prinosa, a većina njih se plašila slabljenja položaja nacionalnih šampiona u svetskoj trgovini. Glavna ideja za ovu vrstu industrijske politike, kao što objašnjavaju M. Richardson i S. Knowles (1999), jeste da ograničavanjem broja preduzeća na tržištu, vlada može lakše implementirati neke ciljeve ekonomske politike, kao što je povećanje udela razmenjivih dobara $\mathrm{u}$ industrijskoj proizvodnji. Istovremeno, velika koncentracija omogućava preduzećima da ostvare visok profit, i na taj način vlada pruža značajne podsticaje preduzećima za ostvarivanje ciljeva njene industrijske politike. Stoga, M. Richardson i S. Knowles (1999) zaključuju da su neke zemlje u razvoju sprovele kombinaciju politike zaštite konkurencije i industrijske politike koja kontroliše broj preduzeća na tržištu. Prema A. Amsden-u i A. Singh-u (1994) i A. Singh-u (2002), ove zemlje su tražile optimalan nivo konkurencije za promovisanje dinamičke efikasnosti.

Ilustracija prethodnog pristupa može se naći u japanskoj politici konkurencije između 1950. i 1973, kada je Japan bio u poziciji zemlje u razvoju, kako navode A. Singh i R. Dhumale (2001). U tom periodu, industrijska politika bila je važnija za vladu nego politika konkurencije i podsticana su spajanja velikih preduzeća $\mathrm{u}$ nekim strateškim granama idejom da visoke stope štednje i investicija mogu da ostvare samo velika preduzeća. A. Amsden i A. Singh (1994) objašnjavaju da je optimalna kombinacija konkurencije i saradnje zavisila od faze u kojoj se nalazi grana. U mladim granama konkurencija je potisnuta, u fazi tehnološke zrelosti podstaknuta je konkurencija, i u opadajućoj fazi je ponovo potisnuta. Ova politika donela je visoke stope privrednog rasta, a paradoksalni rezultat je da iako je industrijska politika dominirala, nivo koncentracije u pojedinim granama je opao zbog ulaska i veće proizvodnje malih preduzeća. U ovom slučaju, ekonomski rast je smanjio koncentraciju.

Ista politika primenjena je u Južnoj Koreji i, takođe, rezultirala je visokim stopama ekonomskog rasta. B. Song (1994) tvrdi da je udeo tri najveća preduzeća u industrijskoj proizvodnji u Južnoj Koreji bio 62\%, dok je ista mera za američku privredu tri puta niža. Međutim, ekonomski rast nije rezultirao smanjenjem koncentracije, s obzirom na to da je rast uglavnom bio ostvaren većom proizvodnjom velikih preduzeća.

Ipak, poslednjih decenija postalo je jasno da je izlaganje konkurenciji najbolji način da se ojačaju kapaciteti preduzeća i čitave grane da bi uspešno konkurisali na međunarodnom tržištu. 
Stagnacija japanske privrede od 1994, pokazala je da, nakon prve faze razvoja, industrijska politika mora da bude podređena politici konkurencije. D. Açemoglu, P. Aghion i F. Zilibotti (2003) tvrde da su visoke stope štednje i akumulacije faktora važne za manje i srednje razvijene zemlje, gde ograničena konkurencija može biti korisna za ekonomski rast. Ali, kad zemlja postane razvijena, potencijal rasta kroz akumulaciju faktora se smanjuje. $U$ toj fazi ekonomija se zasniva na znanju i sofisticiranim inovacijama koje zahtevaju veću konkurenciju.

U nekim zemljama u razvoju, visoka koncentracija je posledica dominantnog položaja preduzeća $u$ državnom vlasništvu, stremljenja za rentom od strane privatnih preduzeća i visokih barijera ulasku (Parker \& Kirkpatrick, 2004). Visoka koncentracija, takođe, stvara velike podsticaje za formiranje kartela. Dosluh može uključiti lokalne vlasti i kompanije sa dominantnim položajem na lokalnom tržištu u obliku administrativno nametnutih barijera za ulazak. U tom slučaju, velika koncentracija predstavlja prepreku ekonomskom razvoju.

Teorijska literatura koja se bavi uticajem konkurencije na ekonomski rast ukazuje na to da konkurencija može povećati ili smanjiti ekonomski rast, dok empirijska literatura, uglavnom, pronalazi pozitivan uticaj konkurencije na ekonomski rast. U teorijskoj literaturi se uticaj zaštite konkurencije meri kroz njen uticaj na inovacije, a inovacije, sa druge strane, predstavljaju najznačajniji faktor ekonomskog rasta.

Negativan efekat konkurencije na inovacije opisali su P. Aghion i R. Griffith (2008) u Hotelingovom modelu, gde je viši nivo konkurencije predstavljen smanjenjem transportnih troškova. Veća konkurencija smanjuje profit preduzeća i njihov podsticaj za inovacije. Isti zaključak se dobija u Dixit-Stiglitzovom modelu monopolističke konkurencije, gde je veća konkurencija predstavljena većom zamenljivošću između proizvoda. Još jedna mogućnost je predstavljena u J. A. Schumpeter-ovom (1954) modelu lestvica kvaliteta P. Aghion-a i P. Howitt-a (1998), gde je zaštita svojinskih prava korisna za ekonomski rast, a veća konkurencija negativno utiče na ekonomski rast kroz niži profit inovatora.
P. Aghion i R. Griffith (2008) pozitivan efekat konkurencije na inovacije objašnjavaju efektom rasipanja rente na tržištu sa monopolistom i pridošlicom. Monopolista može da spreči ulazak i da zadrži monopolski profit ulaganjem $u$ inovacije. $\mathrm{U}$ suprotnom, on ima duopolski profit. S druge strane, profit pridošlice je 0 ako ostane van grane $i$ dobija duopolski profit ako uđe u granu. Rasipanje rente postoji ako je razlika između monopolskog i duopolskog profita veća od duopolskog profita, što znači da je monopolista više motivisan za inovacije nego pridošlica. Drugo objašnjenje je predstavljeno $u$ modelu vertikalne diferencijacije, u kome preduzeća imaju različite troškove. Preduzeća sa niskim troškovima imaju veći udeo na tržištu i to će motivisati ulazak novih preduzeća sa niskim troškovima. Štaviše, veća konkurencija će navesti preduzeća sa visokim troškovima da inoviraju proizvodni proces, kako bi postala preduzeća sa niskim troškovima.

Postoje neki metodološki problemi koji su P. Aghion i R. Griffith (2008) identifikovali u odnosu između veličine preduzeća i inovacija. Prvi problem je da se veličina preduzeća nalazi $u$ pozitivnoj korelaciji sa njegovom starošću, i da starija preduzeća više inoviraju. Drugi problem je obrnuta uzročnost, tj. da preduzeća koja inoviraju dobijaju tržišni udeo i veličina preduzeća je posledica inovativnih napora. Poslednji aspekt je da čak iako veća preduzeća više inoviraju, na tržištu postoji više preduzeća i efekat na ukupne inovacije nije očigledan.

Interesantan pristup $\mathrm{u}$ kome intenziteti konkurencije i inovacija zavise od nivoa asimetrične informisanosti predstavili su P. Aghion, M. Dewatripont i P. Rey (1999). Oni pretpostavljaju da preduzeća mogu imati dva moguća oblika ponašanja: maksimiziranje profita i konzervativno ponašanje. U slučaju maksimiziranja profita, konkurencija smanjuje koristi od istraživanja i razvoja za pojedinačno preduzeće i ukupnu količinu istraživanja u grani. Prema tome, pod ovom pretpostavkom, veća konkurencija smanjuje endogenu stopu rasta. Pod pretpostavkom konzervativnog ponašanja, preduzeća imaju privatne troškove uvođenja inovacija i imaju motivaciju da odlažu uvođenje nove tehnologije do poslednjeg trenutka pre nego što stara tehnologija postane beskorisna. 
Veća konkurencija smanjuje životni vek tehnologija, što znači da će preduzeća ranije uvesti nove tehnologije, i u tom slučaju, veća konkurencija dovodi do veće endogene stope privrednog rasta. Ponašanje preduzeća može se učiniti endogenim u modelu kada je vezano za veličinu agencijskog problema između menadžera i vlasnika. Ako je problem asimetrične informisanosti nizak, preduzeća maksimiziraju profit, ali, ako je problem asimetrične informisanosti visok, preduzeća usvajaju konzervativno ponašanje, što nudi važne preporuke za zemlje u razvoju gde su problemi asimetrične informisanosti viši nego $u$ razvijenim zemljama. U tom slučaju, veća konkurencija je korisna za ekonomski rast.

Što se tiče empirijskog odnosa između konkurencije i inovacija, S. J. Nickell (1996) meri inovacije ukupnom faktorskom produktivnošću (TFP) i pronalazi da je stopa rasta TFP veća u konkurentnijim granama. Isti rezultat dobijaju R. Blundell, R. Griffith i J. Van Reenen (1999), koji pronalaze veću stopu inovacija u konkurentnijim granama. Korišćenjem mikro podataka, G. R. Clarke (2011) zaključuje da zemlje sa strožijim zakonima o konkurenciji imaju više inovacija, ali da veća cenovna konkurencija smanjuje inovacije.

P. Rey (1997) razmatra uticaj zaštite konkurencije na ekonomski razvoj. U zemljama u razvoju, koncentracija na tržištu je visoka u nekim granama sa visokim preprekama za ulazak, što podrazumeva da su odgovarajuća kontrola spajanja i sprečavanje nastanka kartela važni elementi ekonomskog razvoja. Osnovna pretpostavka je da visoka koncentracija ne povećava dinamičku efikasnost.

Drugi aspekt odnosi se na predatorsko ponašanje, kada dominantno preduzeće na tržištu može pokrenuti cenovni rat, smanjiti novčani tok malog preduzeća, i povećati mu kamatnu stopu za nove kredite. Zbog činjenice da su mogućnosti za finansiranje $\mathrm{u}$ zemljama $\mathrm{u}$ razvoju oskudnije, a informaciona asimetrija veća na tržištu kredita, predatorsko ponašanje je važnije pitanje u zemljama u razvoju nego u razvijenim zemljama. Stoga, politika zaštite konkurencije koja sprečava predatorsko ponašanje koristi ekonomskom razvoju.
U empirijskoj literaturi vezanoj za uticaj politike zaštite konkurencije na ekonomski razvoj, ključno pitanje je izbor promenljive koja meri politiku zaštite konkurencije i njenu efikasnost. Jedna mera je Indeks zakona o zaštiti konkurencije (Antitrust Law Index - ALI), koji se sastoji od nekoliko podindeksa. Prvi razmatra sankcije koje komisije za zaštitu konkurencije mogu izreći u vidu novčanih ili zatvorskih kazni. Drugi je vezan za politiku spajanja preduzeća. Treća dimenzija pokriva kartelske sporazume i poslednja ograničenja trgovine.

Postoje i alternativni pristupi u literaturi za merenje postojanja politike zaštite konkurencije. Prvi je binarni pristup, koji koristi promenljivu sa vrednošću 1 ako je usvojen zakon o zaštiti konkurencije i $0 \mathrm{u}$ suprotnom. Drugi pristup je da se koriste mere inputa, kao što su budžet Komisije za zaštitu konkurenciju, ili izlazne promenljive poput broja istraženih slučajeva ili broja žalbi sudu protiv odluka Komisije. Da bi bila uzeta u obzir veličina privrede, budžet Komisije treba podeliti sa brojem zaposlenih ili staviti u odnos sa društvenim proizvodom.

M. W. Nicholson (2008) pokazuje da indeks zakona o zaštiti konkurencije (ALI) nije odgovarajuća mera efikasnosti ove politike. Svetski ekonomski forum (WEF) objavljuje indikator koji obuhvata delotvornu primenu zakona i izračunava se na osnovu mišljenja poslovnih lidera o efikasnosti politike zaštite konkurencije. Paradoks koji je identifikovao M. W. Nicholson (2008) jeste da ALI ima najveću vrednost za privrede $u$ tranziciji, ali u ovim zemljama zakoni nisu praćeni efikasnom primenom. Naime, korelacija između indeksa WEF i ALI je -0,198, što ukazuje na to da zemlje koje imaju formalno strožije zakone imaju manje efektivnu primenu u praksi.

Uticaj zaštite konkurencije na ekonomski razvoj prema M. Krakowski-om (2005) može se oceniti $\mathrm{u}$ tri faze. U prvoj fazi, efikasna primena politike zaštite konkurencije zasnovana na WEF indeksu je zavisna promenljiva, a nezavisne promenljive su postojanje politike zaštite konkurencije, iskustvo Komisije, i efikasnost vlade u primeni ekonomske politike. Rezultati pokazuju da su statistički značajne promenljive koje se odnose na iskustvo Komisije za zaštitu konkurenciju i vladino iskustvo u primeni 
ekonomske politike. U drugoj fazi, intenzitet konkurencije zasnovan na WEF istraživanju je zavisna promenljiva. Rezultati pokazuju da su od nezavisnih promenljivih, efikasnost politike zaštite konkurencije i BNP značajne, dok promenljive spoljno-trgovinske zaštite (carine, kvote i necarinske barijere) nisu značajne. U poslednjoj fazi BNP per capita je zavisna promenljiva, dok je intenzitet konkurencije nezavisna promenljiva i dokazuje se da privrede sa višim nivoom konkurencije imaju viši nivo ekonomskog razvoja.

Empirijsku analizu sprovođenja politike zaštite konkurencije u tranzicionim zemljama izvršili su M. A. Dutz i M. Vagliasindi (2000). Oni mere sprovođenje politike zaštite konkurencije $u$ tri dimenzije: sprovođenje, ekonomske politike koje podstiču zaštitu konkurencije, i institucionalna efikasnost.

Sprovođenje meri delotvornu primenu politike zaštite konkurencije prema preduzećima. Sastoji se od poddimenzija, kao što su zloupotreba dominantnog položaja, kartelsko udruživanje, i spajanje preduzeća. Ekonomske politike koje podstiču zaštitu konkurencije se odnose na veliki broj različitih ekonomskih politika koje međusobno deluju sa politikom zaštite konkurencije.

Institucionalna efikasnost meri se nezavisnošću i transparentnošću Komisije za zaštitu konkurencije. Uzorak uključuje dvadesetšest zemalja u tranziciji, u Centralnoj i Istočnoj Evropi, kao i nekim postsovjetskim zemljama. Zemlje koje su prvo usvojile politiku zaštite konkurencije, baltičke države i Rumunija, su lideri u njenom sprovođenju. Regresiona analiza pokazuje da sprovođenje zakona i institucionalna efikasnost imaju značajan uticaj na intenzitet konkurencije, dok uticaj ekonomskih politika koje podstiču zaštitu konkurencije nije značajan.

T. C. Ma (2011) analizira uticaj politike zaštite konkurencije na rast BDP-a u razvijenim i zemljama u razvoju u Solow-ljevom modelu rasta. Prisustvo i opseg politike zaštite konkurencije su obuhvaćeni promenljivom SCOPE, koja je definisana $\mathrm{u}$ radu $\mathrm{K}$. N. Hylton-a i F. Deng-a (2007). Opšta efektivnost vladine primene politika, a ne samo politike zaštite konkurencije, obuhvaćena je promenljivom
EFFICIENCY koja je definisana u radu D. Kaufmann, A. Kraay i M. Mastruzzi (2009). Rezultati pokazuju da promenljiva SCOPE nije značajna i da formalno postojanje zakona o zaštiti konkurencije ne može uticati na ekonomski rast. Interaktivna promenljiva SCOPE $x$ EFFICIENCY naziva se EFFLAV. Za nerazvijene zemlje koeficijent za ovu promenljivu je 0,04, i statistički je značajan, a za razvijene zemlje koeficijent je 0,064, i, takođe, je statistički značajan. Stoga, zakon mora biti dopunjen efikasnim sprovođenjem politike.

\section{METODOLOGIJA UZORKOVANJA}

Termin zemlja u razvoju se obično koristi za označavanje zemlje koja ima relativno nizak životni standard, nerazvijenu industriju i niži nivo ukupnog blagostanja u odnosu na više (ekonomski) razvijene zemlje. Različite institucije koriste različite granice materijalnog i nematerijalnog bogatstva da klasifikuju pojedine zemlje $\mathrm{u}$ određene kategorije razvoja $\mathrm{i}$ izuzetno je teško precizno odgovoriti na pitanje koliko bi zemlja trebalo da bude (ili ne bude) bogata da bi bila smatrana zemljom u razvoju. Čak i među zemljama u razvoju, postoje očigledne razlike u nivou ekonomskog i društvenog razvoja. Ovi problemi doveli su do široko rasprostranjene debate o upotrebi termina zemlja u razvoju u poslednjih nekoliko godina, pa su međunarodne organizacije ublažile svoj pristup, ili čak ne prave razliku između razvijenih i zemalja u razvoju.

BDP, ili dohodak per capita, se obično smatraju početnim kriterijumima za klasifikaciju zemalja $\mathrm{u}$ različite faze razvoja. Svetska banka klasifikuje zemlje prema bruto nacionalnom dohotku per capita $\mathrm{u}$ četiri grupe: zemlje sa niskim dohotkom, zemlje sa nižim srednjim dohotkom, zemlje sa višim srednjim dohotkom, i zemlje sa visokim dohotkom. Druge institucije koriste nešto drugačije šeme klasifikacije. Na primer, Međunarodni monetarni fond primenjuje fleksibilniji sistem klasifikacije, uzimajući u obzir dohodak per capita, diversifikaciju izvoza, i stepen integracije u globalni finansijski sistem. Prema ova tri kriterijuma, zemlje se klasifikuju u razvijene i zemlje u razvoju. 
Do 2004, MMF je sve zemlje Centralne i Istočne Evrope, kao i bivše zemlje Sovjetskog Saveza u Centralnoj Aziji i Mongoliju, svrstavao u zemlje $\mathrm{u}$ tranziciji, dok danas sve pripadaju zemljama $\mathrm{u}$ razvoju. UNDP razvrstava zemlje u tri kategorije: razvijene, zemlje $u$ tranziciji, i zemlje u razvoju. Zemlje u razvoju i zemlje $\mathrm{u}$ tranziciji se dodatno dele na izvoznice nafte, dok značajan procenat zemalja u razvoju pripada grupi najmanje razvijenih zemalja. Zemlje u razvoju su, takođe, podeljene na zemlje bez izlaza na more i male ostrvske zemlje.

Pri odlučivanju koje zemlje treba uključiti $u$ naš uzorak, započeli smo sa listom zemalja prema klasifikaciji Svetske banke iz decembra 2016. U početku smo uključili sve zemlje sa nižim i višim srednjim dohotkom, ukupno sedamdeset. Da bismo izbegli ekstremna neslaganja $\mathrm{u}$ pogledu dohotka, odlučili smo da isključimo zemlje sa niskim dohotkom iz analize, iako su do nedavno one, takođe, bile razmatrane kao zemlje $u$ razvoju. Dalja istraživanja su pokazala da šestdeset od sedamdeset inicijalno razmatranih zemalja ima zakon o zaštiti konkurencije, tako da konačan uzorak sadrži šestdeset zemalja. A. Singh (2002) navodi da je ovo znatno poboljšanje u poređenju sa 1990, kad je samo šestnaest zemalja u razvoju imalo zakon o zaštiti konkurencije. Svetska trgovinska organizacija i druge međunarodne institucije su pomogle $\mathrm{u}$ usvajanju zakona o zaštiti konkurencije.

Iako posmatrane zemlje čine prilično heterogenu kategoriju, ipak će rezultati istraživanja biti od velikog značaja jer će testiranje polazne hipoteze dati odgovor $\mathrm{u}$ pogledu značaja efikasne primene politike zaštite konkurencije za ekonomski razvoj.

\section{INDIKATORI EFEKTIVNE PRIMENE POLITIKA ZAŠTITE KONKURENCIJE I EKONOMSKI RAZVOJ}

Pre nego što testiramo polaznu hipotezu ovog istraživanja, analiziramo pojedinačne pokazatelje koji će se koristiti kao promenljive u regresionom modelu. Kao indikator efikasne primene politike zaštite konkurencije koristimo indeks koji objavljuje Svetski ekonomski forum (WEF, 2016). WEF je kreirao niz indikatora za merenje i upoređivanje konkurentnosti nacionalnih privreda. Indikator koji se koristi od 2005. naziva se Globalni indeks konkurentnosti (GCI), i pretpostavlja da postoje brojni faktori koji objašnjavaju konkurentnost nacionalnih privreda. Važna karakteristika GCI je da su svi faktori konkurentnosti grupisani u 12 kategorija, tj. 12 stubova konkurentnosti.

U cilju kreiranja indeksa globalne konkurentnosti, WEF koristi ukupno 114 faktora konkurentnosti. Podaci korišćeni $u$ istraživanju dobijeni su na dva načina: direktno merenje (kvantitativni podaci) dobijeni iz relevantnih statističkih podataka i međunarodnih institucija i podaci iz anketa o mišljenju rukovodilaca preduzeća, pri čemu se podaci dobijaju putem intervjua sa predstavnicima poslovne zajednice. WEF uključuje većinu faktora koji su ključni za ekonomski rast i razvoj: institucije, makroekonomski faktori, infrastruktura, obrazovanje, tehnologija i još mnogo toga. Svake godine, WEF sprovodi anketu koja obuhvata značajan broj zemalja. Ispitanici su poslovni lideri koji ocenjuju efikasnost politike zaštite konkurencije u svojoj zemlji. Efikasnost politike zaštite konkurencije se meri skalom od 1 do 7 . Ocena 1 znači da je politika konkurencije slaba i neefikasna, a ocena 7 predstavlja efikasnu zaštitu konkurencije. Jedan od nedostataka GCI-a, kao i pojedinačnih faktora, jeste činjenica da se indeksi uglavnom oslanjaju na podatke dobijene iz različitih istraživanja, što donekle donosi pristrasne procene i može uticati na ishod istraživanja. Međutim, u svrhu ove studije, podaci koji se koriste mogu se smatrati relevantnim.

Zavisna promenljiva u regresionoj analizi je BDP per capita, kao pokazatelj ekonomskog razvoja. BDP per capita za 2015. prikazan je na Slici 1.

Prosečan BDP per capita za posmatrane zemlje iznosi oko 5000 USD. Argentina, Panama i Kostarika imaju vrlo visok nivo BDP-a per capita, u poređenju sa preostalim zemljama. Negativan uticaj ovih ekstremnih vrednosti na ocenjenu regresiju neutrališemo uvođenjem veštačke promenljive. Takav 


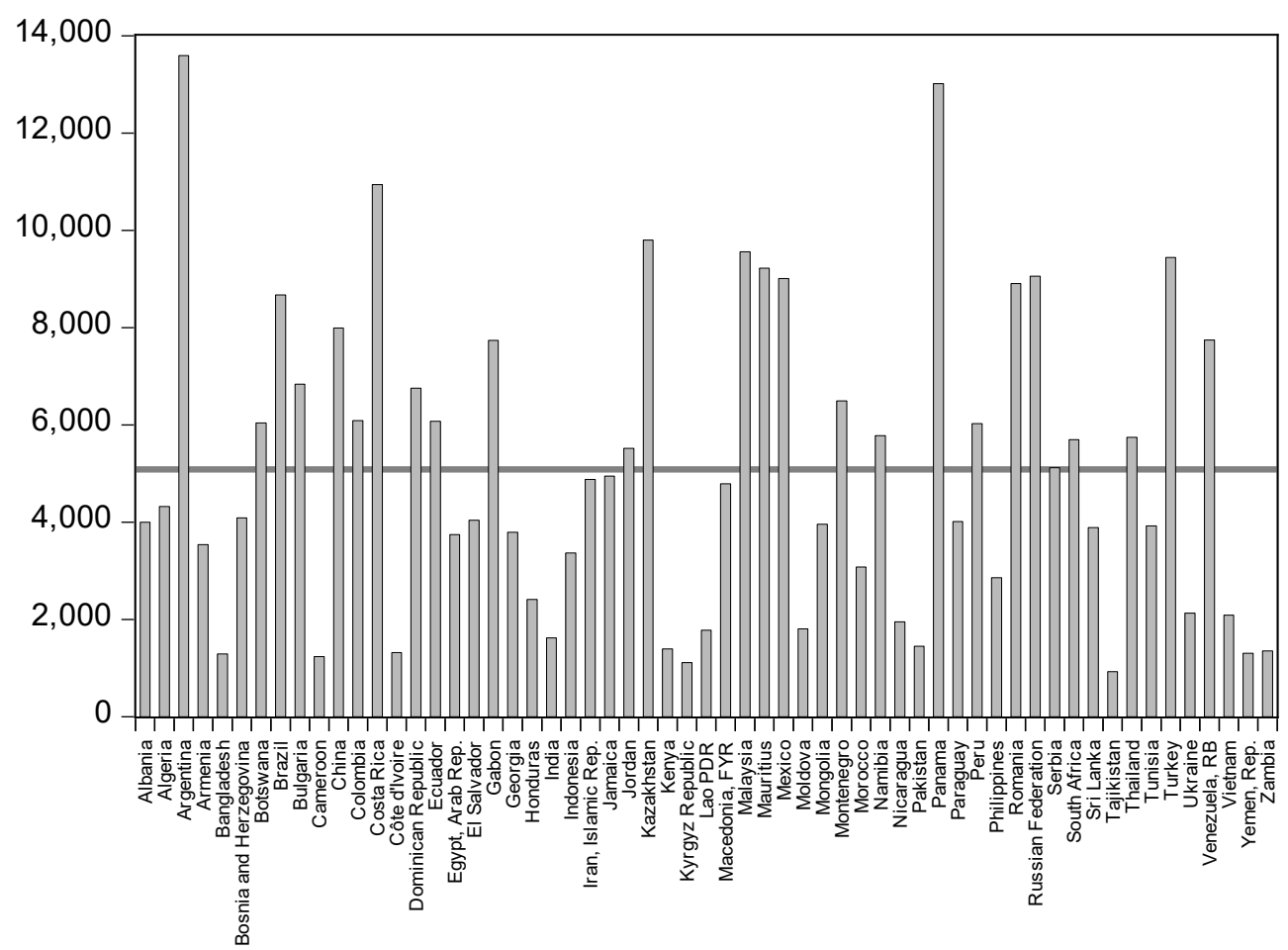

Slika 1 BDP per capita u 2015. (USD)

Izvor: Svetska banka

visok nivo razvoja Argentine i dve druge zemlje u Centralnoj Americi, kako navode A. Saravia, C. Machicado i F. Rioja (2014), ostvaren je zbog visoke produktivnosti u poljoprivredi, što je omogućilo ovim zemljama da počnu relativno rano sa procesom industrijalizacije.

Komparativna analiza efektivne primene politike zaštite konkurencije data je na Slici 2, koja pokazuje da je prosečna vrednost ovog indikatora za zemlje u uzorku oko 3,5. Južna Afrika ima najvišu ocenu, a najlošije ocenjena država u efikasnoj primeni politike zaštite konkurencije je Venecuela. Južna Afrika je usvojila Zakon o zaštiti konkurencije 1999, kada je prepoznala potrebu za jakom politikom zaštite konkurencije zbog visokog nivoa koncentracije $\mathrm{u}$ privredi (Roberts, 2004).

Pored prethodnih promenljivih, uključili smo $\mathrm{u}$ analizu sledeće nezavisne promenljive: indeks potrošačkih cena, izvoz robe i usluga (\% BDP-a), rast stanovništva, trajanje postupka za registraciju preduzeća (broj dana), i stopa nezaposlenosti (\% ukupne radne snage).

Najveći indeks potrošačkih cena ostvaren je u Rusiji i Iranu, dok su u Tajlandu, Jordanu i Rumuniji u 2015. bili najmanji (negativni) indeksi potrošačkih cena. Većina zemalja sa niskim nivoom inflacije primenjuje politiku ciljanja inflacije (Volz, 2015).

Izvoz robe i usluga zemalja u uzorku je prosečno 35\% BDP-a. Najveće učešće izvoza u BDP-u ima Vijetnam, $80 \%$, dok su na dnu Jemen, Tadžikistan i Pakistan (10\% BDP-a).

Prosečna stopa rasta stanovništva u uzorku je 1,2\% (Slika 3). Najveća stopa u 2015, zabeležena je u Zambiji i Keniji, dok se Bugarska, Republika Srbija i Rumunija, suočavaju sa negativnim rastom stanovništva, što predstavlja prepreku razvoju, jer starenje stanovništva preusmerava sredstva od investiranja $u$ 


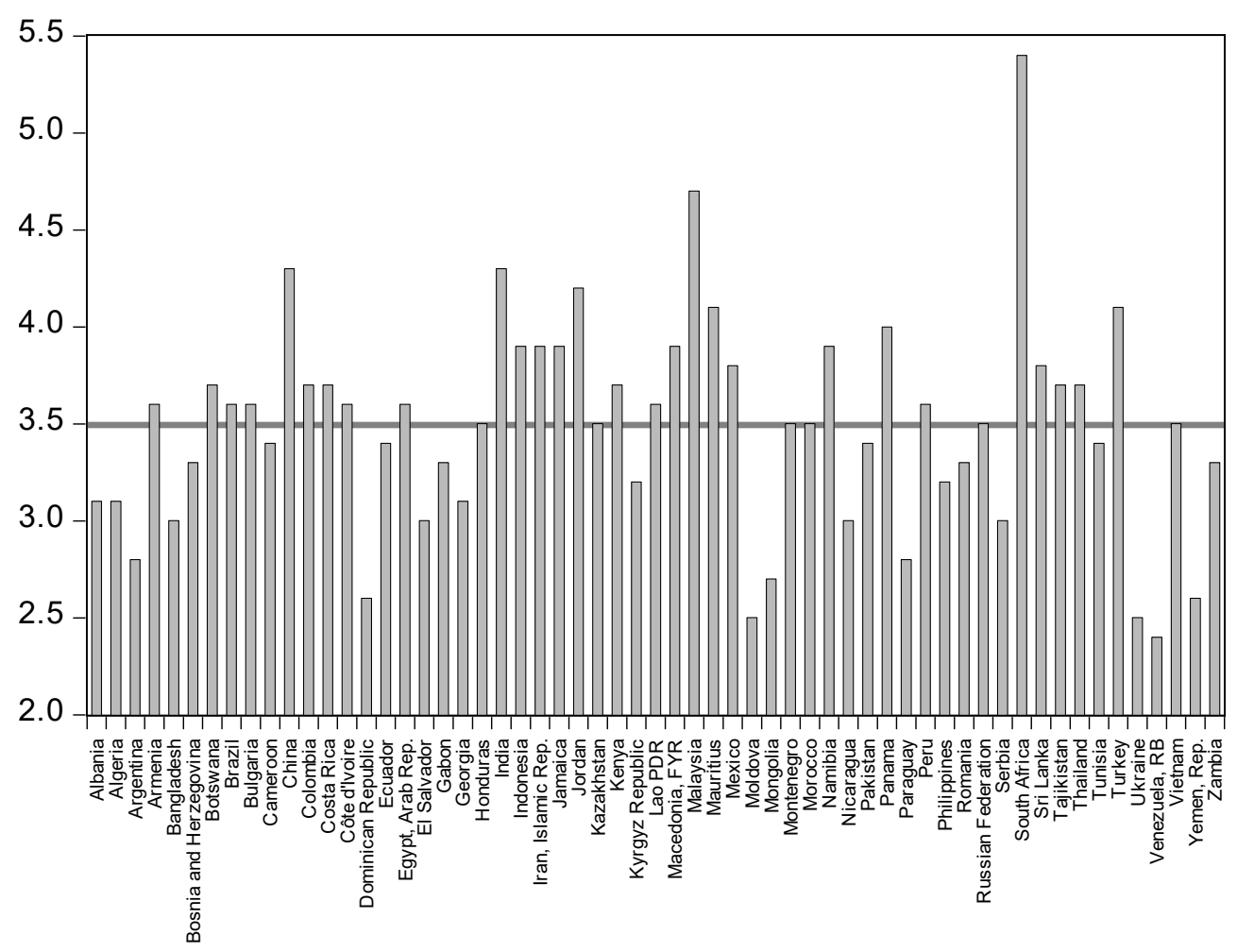

Slika 2 Efektivna primena zaštite konkurencije

Izvor: WEF, 2016

ekonomski razvoj ka zdravstvenoj zaštiti i penzionom sistemu (Teixeira, Renuga Nagarajan \& Silva, 2016). Interesantna analizu odnosa zagađenja, fertiliteta i BDP per capita izvršili su D. Varvarigos i I. Z. Zakaria (2017).

Prosečno je potrebno oko osam dana za registraciju preduzeća u odabranim zemljama. Najbolju ocenu imaju BJR Makedonija i Jamajka, dok su najlošije ocenjene Venecuela i Filipini.

Najveće stope nezaposlenosti imaju BJR Makedonija, BiH i Južna Afrika (iznad 20\%), dok Tajland ima stopu nezaposlenosti blizu 0 (Slika 4). Prema H. Feldmann-u (2008), stopa nezaposlenosti $u$ privredama $u$ razvoju mogla bi se smanjiti putem kooperativnih industrijskih odnosa koji smanjuju stopu otpuštanja.

\section{UTICAJ ZAŠTITE KONKURENCIJE NA EKONOMSKI RAZVOJ}

U ovom delu ćemo testirati hipotezu da postoji pozitivan uticaj efikasne primene politike zaštite konkurencije na ekonomski razvoj zemalja $u$ razvoju. U tom cilju, koristićemo prethodno opisane i analizirane indikatore. Ocenili smo linearnu regresiju sledećeg oblika:

$$
\begin{aligned}
& G D P_{-} p c=\beta_{0}+\beta_{1} W E F+\beta_{2} C P I+\beta_{3} E X P+\beta_{4} P O P G \\
& +\beta_{5} S T A R T U P+\beta_{6} U N E M P L O Y M E N T+\varepsilon
\end{aligned}
$$

gde zavisna promenljiva GDP per capita meri nivo razvoja. Prethodno pomenuti indikatori koriste se kao nezavisne promenljive: WEF (efektivna politika zaštite konkurencije), CPI (stopa inflacije), EXP (učešće izvoza u BDP-u), STARTUP (procedure za registraciju preduzeća), UNEMPLOYMENT (stopa 


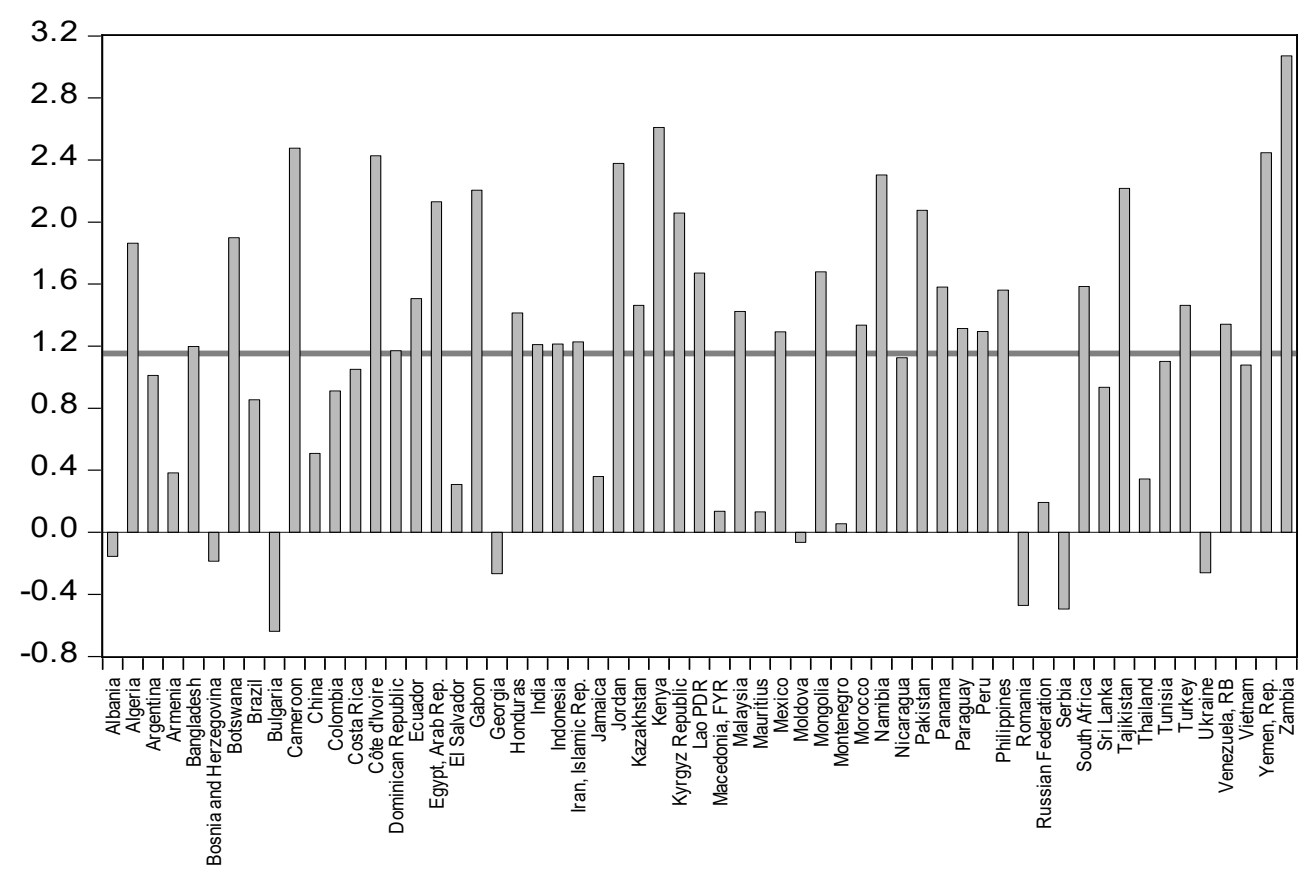

Slika 3 Rast stanovništva 2015.

Izvor: Svetska banka

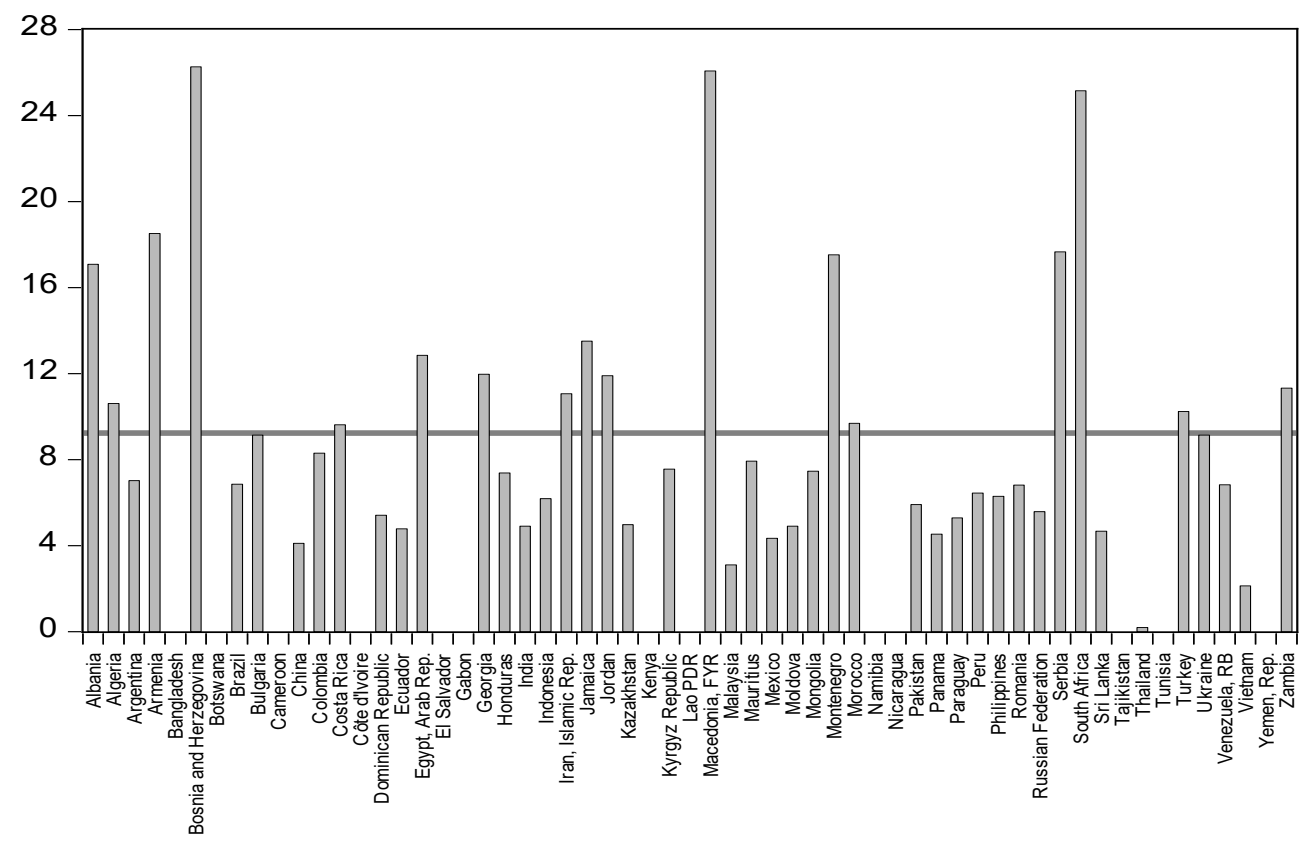

Slika 4 Stopa nezaposlenosti (\% radne snage) 2015.

Izvor: Svetska banka 
nezaposlenosti). U početnom modelu, promenljive CPI, EXP i STARTUP nisu statistički značajne i isključene su iz dalje analize. Početni model je dat $u$ dodatku.

Nakon isključivanja promenljivih, koje nisu značajne, ocenili smo redukovani oblik modela. U drugoj regresiji dodali smo veštačku promenljivu koja eliminiše izuzetno visoke vrednosti BDP-a per capita za tri zemlje: Argentina, Kostarika i Panama. Veštačka promenljiva uzima vrednost 1 za ove zemlje i $0 \mathrm{u}$ suprotnom. Ocenjeni model pokazuje da su svi koeficijenti statistički značajni na nivou od $10 \%$ značajnosti, dok koeficijent za stopu nezaposlenosti nije statistički značajan na nivou od 5\%. Poslednji rezultat je zahtevao detaljniju analizu reziduala ocenjenog modela, kojim je utvrđeno da je rezidual imao najvišu apsolutnu vrednost za Indiju, jer BDP per capita i stopa nezaposlenosti nisu konzistentni. Nizak stepen nezaposlenosti imaju zemlje sa visokim BDP-om per capita, i obrnuto. Pošto to nije slučaj, dodali smo još jednu veštačku promenljivu koja ima vrednost 1 za Indiju i 0 za druge zemlje. Uvođenjem dve veštačke promenljive, napravili smo konačni model koji je korišćen za testiranje glavne hipoteze:

$$
\begin{aligned}
& G D P_{-} p c=\beta_{0}+\beta_{1} W E F+\beta_{2} C P I+\beta_{2} P O P G \\
& +\beta_{3} U N E M P L O Y M E N T+\beta_{4} D U M+\beta_{4} D U M_{2}+\varepsilon
\end{aligned}
$$

Ocenjeni model pokazuje da su sve promenljive statistički značajne, uključujući dve veštačke promenljive sa nivoom značajnosti od $5 \%$.

Da bi se testirala validnost modela, neophodni su dodatni ekonometrijski testovi. Prvo, treba utvrditi da li postoji autokorelacija reziduala. Vrednost DurbinWatson statistike je 2,25, i na osnovu toga hipoteza o postojanju autokorelacije prvog reda može biti odbačena.

Do istog zaključka se dolazi analizom korelograma. Nakon testiranja autokorelacije, testiramo normalnost reziduala. Vrednost Jarque-Bera statistike je 1,06 sa $p$ vrednošću 0,59 , što znači da na nivou značajnosti $\alpha=$ 0,05 , ne možemo odbaciti hipotezu da reziduali imaju normalnu raspodelu.
Tabela 1 Ocenjeni model

\begin{tabular}{l|llll}
\hline Variable & Coeff. & $\begin{array}{l}\text { Std. } \\
\text { Error }\end{array}$ & t-Statistic & Prob. \\
C & 818.9172 & 2055.959 & 0.398314 & 0.6925 \\
\hline WEF_VALUE & 1909.741 & 599.4599 & 3.185769 & 0.0028 \\
POPG & -1011.617 & 412.9202 & -2.449910 & 0.0188 \\
UNEMP & -135.8814 & 58.85549 & -2.308729 & 0.0262 \\
DUM & 7196.002 & 1334.294 & 5.393118 & 0.0000 \\
DUM2 & -5524.342 & 2315.986 & -2.385309 & 0.0219 \\
\hline R-squared & 0.546669 & Mean dependent var & 5661.415 \\
$\begin{array}{l}\text { Adj. R-sq. } \\
\begin{array}{l}\text { S.E. of } \\
\text { regression }\end{array}\end{array}$ & 0.490002 & S.D. dependent var & 3103.315 \\
$\begin{array}{l}\text { Sum squ. } \\
\text { Resid }\end{array}$ & $1.96 \mathrm{E}+08$ & Schwarz criterion & 18.60461 \\
$\begin{array}{l}\text { Log likelihood } \\
\begin{array}{l}\text { F-statistic } \\
\text { Prob }\end{array}\end{array}$ & -416.4200 & Hannan-Quinn criter. & 18.45544 \\
(F-statistic) & 9.647135 & Durbin-Watson stat & 2.257815 \\
\hline
\end{tabular}

Izvor: Rezultati ocenjenog modela u programu Eviews

Test heteroskedastičnosti reziduala se vrši primenom White-ovog testa. Vrednosti $F$ i $\chi^{2}$ statistika su 1,35 i 16,29 , sa odgovarajućim $p$ vrednostima od 0,23 i 0,23 respektivno, što implicira da na nivou statističke značajnosti $5 \%$, ne možemo odbaciti hipotezu o odsustvu heteroskedastičnosti i regularnosti linearnog oblika modela. Iz matrice korelacije nezavisnih promenljivih može se zaključiti da $u$ modelu nema multikolinearnosti.

Najvažniji zaključak regresione analize je to što je utvrđen pozitivan uticaj efikasne primene politike zaštite konkurencije na ekonomski razvoj zemalja u razvoju na nivou značajnosti od 5\%. Štaviše, cela regresija je statistički značajna sa istim nivoom značajnosti. Koeficijent determinacije je 0,55 , što znači da nezavisne promenljive objašnjavaju $55 \%$ varijacija BDP per capita za zemlje u uzorku. 


\section{ZAKLJUČAK}

Politika zaštite konkurencije ima ulogu zaštite i jačanja tržišne konkurencije, koja, sama po sebi, obezbeđuje ekonomski efikasne ishode. Ipak, povećana ekonomska efikasnost nije uvek bila glavni ili jedini cilj politike konkurencije. Kroz istoriju, određene privrede su dale veći značaj određenim socio-političkim funkcijama politike zaštite konkurencije, dok je u drugim zemljama preovladala težnja da se stvore nacionalni šampioni u odnosu na efikasnu zaštitu konkurencije. Ovakvi pokušaji nisu dali očekivane rezultate, naročito na dugoročnom nivou. Stoga je osnovni cilj ovog rada utvrđivanje pozitivnog uticaja politike zaštite konkurencije na ekonomski razvoj.

Izbor promenljive koja najbolje odražava efektivnost politike zaštite konkurencije pokazala se kao ključno pitanje vezano za merenje uticaja politike zaštite konkurencije na ekonomski razvoj. U postojećoj empirijskoj literaturi, korišćeni su razni jednostavni i složeni indikatori politike zaštite konkurencije. Najvažniji zaključak koji se može postići iz ovih pokušaja procene uticaja politike zaštite konkurencije jeste da samo postojanje zakonodavstva o zaštiti konkurencije nije dovoljno i mora biti dopunjeno njegovim delotvornim sprovođenjem. Ovo je pristup koji smo sledili u našem radu, gde smo izabrali WEF indikator kao aproksimaciju za efektivnu primenu politike zaštite konkurencije.

Ipak, ograničenje prethodne analize je da se WEF indikator zasniva na subjektivnim stavovima o efikasnosti politike zaštite konkurencije. Bilo bi bolje koristiti neki složeni indeks koji bi sadržao objektivnije mere kao što je broj uspešno rešenih predmeta od strane Komisije, ili broj žalbi sudu na odluke Komisije. Ipak, ovi podaci nisu dostupni za sve zemlje i prethodne studije su imale isti problem.

Izbor ostalih nezavisnih promenljivih napravljen je sa ciljem da se izbegne multikolinearnost u modelu. Neke od ovih promenljivih nisu bile statistički značajne u početnoj oceni modela, pa smo ocenili model isključivanjem ovih promenljivih. Potrebno je napomenuti da je moguće uključivati druge nezavisne promenljive da bi se povećala objašnjavajuća moć regresije.
Glavni doprinos ovog rada je $\mathrm{u}$ identifikovanom pozitivnom odnosu između efikasne primene politike zaštite konkurencije i ekonomskog razvoja zemalja u razvoju. Rezultati predstavljeni u ovom radu zasnovani su na uzorku od šestdeset zemalja u razvoju, koje imaju usvojen zakon o zaštiti konkurencije. Polazna hipoteza ovog istraživanja potvrđena je putem linearne regresije, gde je promenljiva WEF veoma statistički značajna. Dodatni ekonometrijski testovi potvrdili su validnost modela. $\mathrm{Na}$ osnovu ovih rezultata, može se zaključiti da efikasno vođenje politike zaštite konkurencije ima pozitivan uticaj na ekonomski razvoj zemalja $u$ razvoju. Iz tog razloga preporučuje se telima koja su zadužena za sprovođenje ekonomske politike $u$ zemljama u razvoju, da se posebna pažnja usmeri na sprovođenje politike zaštite konkurencije.

Dodatna implikacija ovog istraživanja je da modelima privrednog rasta nedostaje važna promenljiva: efikasna primena politike zaštite konkurencije. U okviru Solow-ljevog modela rasta, rezidual obuhvata tehnički napredak, ali i faktor koji smo ovde identifikovali. Međutim, bilo bi teško da se ukupni efekat politike zaštite konkurencije uključi u model rasta, a ne samo njegov uticaj na inovacije.

Jedna moguća tema za buduće istraživanje mogla bi biti procena uticaja politike zaštite konkurencije na ekonomski razvoj određenih sektora privrede, što bi omogućilo kreatorima ekonomske politike da bolje razumeju koji sektori zahtevaju detaljniju kontrolu nivoa konkurencije. Drugo pitanje se odnosi na metodološke aspekte specifikacije modela, njegovu funkcionalnu formu i grupu posmatranih promenljivih.

\section{REFERENCE}

Açemoglu, D., Aghion, P., \& Zilibotti, F. (2006). Distance to frontier, selection, and economic growth. Journal of the European Economic Association, 4(1), 37-74. doi.org/10.1162/ jeea.2006.4.1.37

Aghion, P., \& Howitt, P. (1998). Market structure and the growth process. Review of Economic Dynamics, 1(1), 276-305. doi.org/10.1006/redy.1997.0007 
Aghion, P., Dewatripont, M., \& Rey, P. (1999). Competition, financial discipline and growth. The Review of Economic Studies, 66(4), 825-852. doi.org/10.1111/1467-937X.00110

Aghion, P., \& Griffith, R. (2008). Competition and Growth: Reconciling Theory and Evidence. Cambridge, US: MIT press.

Amsden, A., \& Singh, A. (1994): The optimal degree of competition and dynamic efficiency in Japan and Korea. European Economic Review, 38(3-4), 941-951. doi. org/10.1016/0014-2921(94)90130-9

Blundell, R., Griffith, R., \& Van Reenen, J. (1999). Market share, market value and innovation in a panel of British manufacturing firms. The Review of Economic Studies, 66(3), 529-554. doi.org/10.1111/1467-937X.00097

Clarke, G. R. (2011). Competition policy and innovation in developing countries: Empirical evidence. International Journal of Economics and Finance, 3(3), 38-49. doi:10.5539/ijef. v3n3p38

Disney, R., Haskel, J., \& Heden, Y. (2000). Restructuring and productivity growth in the UK. Research Paper 2000/13, University of Nottingham, UK: Centre for Research on Globalization and Labour Markets, School of Economics.

Dutz, M. A., \& Vagliasindi, M. (2000). Competition policy implementation in transition economies: An empirical assessment. European Economic Review, 44(4), 762-772. doi. org/10.1016/S0014-2921(99)00060-4

Feldmann, H. (2009). The quality of industrial relations and unemployment in developing countries. Review of Development Economics, 13(1), 56-69. doi.org/10.1111/ j.14679361.2008.00459.x

Hylton, K. N., \& Deng, F. (2007). Antitrust around the World: An empirical analysis of the scope of competition laws and their effects. Antitrust Law Journal, 74(2), 271-341.

Kaufmann, D., Kraay, A., \& Mastruzzi, M. (2009). Governance matters viii: Aggregate and individual governance indicators, 1996-2008. Policy Research Working Paper, World Bank.

Krakowski, M. (2005). Competition policy works: The effect of competition policy on the intensity of competition - an international cross-country comparison. HWWA Discussion Paper, Hamburg Institute of International Economics.

Liebenstein, H. (1966). Allocative efficiency vs X-Inefficiency. American Economic Review, 56(3), 392-415
Ma, T. C. (2011). The effect of competition law enforcement on economic growth. Journal of Competition Law and Economics, 7(2), 301-334. doi.org/10.1093/joclec/nhq032

Motta, M. (2002). Competition Policy: Theory and Practice. Cambridge, NY: Cambridge University Press.

Nicholson, M. W. (2008). An antitrust law index for empirical analysis of international competition policy. Journal of Competition Law and Economics, 4(4), 1009-1029. doi. org/10.1093/joclec/nhn009

Nickell, S. J. (1996). Competition and corporate performance. Journal of Political Economy, 104(4), 724-746.

Olley, G. S., \& Pakes, A. (1996). The dynamics of productivity in the telecommunications equipment industry. Econometrica, 64(6), 1263-1297. doi:10.2307/2171831

Parker, D., \& Kirkpatrick, K. (2004). Economic regulation in developing countries: A framework for critical analysis. In P. Cook, K. Kirkpatrick, M. Minogue, \& D. Parker (Eds.). Leading Issues in Competition, Regulation and Development (pp. 92-113). Edward Elgar Publishing.

Rey, P. (1997). Competition policy and economic development. IDEI-Toulouse, September.

Richardson, M., \& Knowles, S. (1999). On the Use of competition policy to enhance the effectiveness of industrial policy. Review of Development Economics, 3(1), 5865. doi.org/10.1111/1467-9361.00051

Roberts, S. (2004). The role for competition policy in economic development: The South African experience. Development Southern Africa, 21(1), 227-243. doi:10.1080/0376835042000181499

Saravia, A., Machicado, C., \& Rioja, F. (2014). Productivity, structural change and Latin American development. Review of Development Economics, 18(3), 610-624. doi.org/10.1111/ rode.12106

Schmidt, K. M. (1997). Managerial incentives and product market competition. Review of Economic Studies, 64(2), 191213. doi:10.2307/2971709

Schumpeter, J. A. (1954). Capitalism, Socialism and Democracy. Unwin University Books, Chapter 7 - "The Process of Creative Destruction"

Singh, A. (2002). Competition and competition policy in emerging markets: International and development dimensions, ESRC centre for business research. Working paper No 246, University of Cambridge. 
Singh, A., \& Dhumale, R. (2001). Competition policy, development, and developing countries. In P. Arestis, M. Baddeley, \& J. McCombie (Eds.). What Global Economic Crisis? (pp. 122-145). Londdon, UK: Palgrave Macmillan.

Song, B. (1994). The Rise of the Korean Economy. Hong Kong: Oxford, Oxford University Press.

Teixeira, A., Renuga Nagarajan, N., \& Silva, S. T. (2016). The impact of ageing and the speed of ageing on the economic growth of least developed, emerging and developed countries, 1990-2013. Review of Development Economics, 21(3), 909-934. doi.org/10.1111/rode.12294
Varvarigos, D., \& Zakaria, I. Z. (2017). Longevity, fertility and economic growth: Do environmental factors matter? Review of Development Economics, 21(1), 43-66. doi.org/10.1111/ rode.12239

Volz, U. (2015). On the future of inflation targeting in East Asia. Review of Development Economics, 19(3), 638-652. doi. org/10.1111/rode.12173

World Economic Forum - WEF. (2016). The Global Competitiveness Report 2016-2017. Geneva.

Primljeno 9. aprila 2018, nakon revizije, prihvaćeno za publikovanje 22. avgusta 2018. Elektronska verzija objavljena 27. avgusta 2018.

Siniša Milošević je rukovodilac Sektora za ekonomske analize Komisije za zaštitu konkurencije Republike Srbije. Doktorirao je na Ekonomskom fakultetu Univerziteta u Beogradu. Objavio je veći broj radova iz oblasti zaštite konkurencije.

Dejan Trifunović je vanredni profesor na Ekonomskom fakultetu Univerziteta u Beogradu, gde je i doktorirao. Izvodi nastavu na predmetima Teorija cena i Industrijska organizacija na osnovnim studijama i na predmetu Mikroekonomija na master i doktorskim studijama. Oblasti njegovog naučnog interesovanja su teorija igara, aukcije, uparivanje, asimetrične informacije, mrežne eksternalije, i zaštita konkurencije.

Jelena Popović Markopoulos je viši savetnik u Sektoru za ekonomske analize Komisije za zaštitu konkurencije Republike Srbije. Master studije je završila na Univerzitetu Tor Vergata u Rimu i na Ekonomskom fakultetu Univerziteta u Beogradu. Na doktorskim je studijama na Ekonomskom fakultetu u Beogradu. Oblast njenog naučnog interesovanja je zaštita konkurencije. 


\title{
THE IMPACT OF THE COMPETITION POLICY ON ECONOMIC DEVELOPMENT IN THE CASE OF DEVELOPING COUNTRIES
}

\author{
Siniša Milošević', Dejan Trifunović́ and Jelena Popović Markopoulos ${ }^{1}$ \\ 'Commission for Protection of Competition, The Republic of Serbia \\ ${ }^{2}$ Faculty of Economics, University of Belgrade, Belgrade, The Republic of Serbia
}

In this paper, we will analyse the impact of the effective application of the competition policy to the economic development of developing countries. Many empirical papers suggest that the existence of the competition policy does not significantly affect the level of the GDP per capita, and that only its effective application is important. We will take the same approach and use the World Economic Forum index as a proxy for the effective application of the competition policy. We will demonstrate that a part of the variations in the GDP per capita between developing countries could be explained by an effective application of the competition policy.

Keywords: competition policy, intensity of competition, economic development, developing countries

JEL Classification: L51, 012 